\title{
Ag/MgO Nanoparticles via Gas Aggregation Nanocluster Source for Perovskite Solar Cell Engineering
}

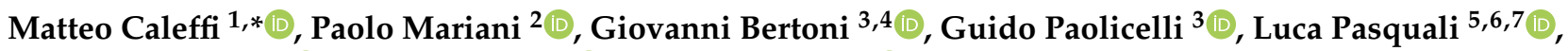 \\ Antonio Agresti ${ }^{2, *}\left(\mathbb{D}\right.$, Sara Pescetelli ${ }^{2}\left(\mathbb{D}\right.$, Aldo Di Carlo ${ }^{2,8}\left(\mathbb{D}\right.$, Valentina De Renzi ${ }^{1,3}$ and Sergio $D^{\prime}$ Addato ${ }^{1,3,9}$ \\ 1 Dipartimento di Scienze Fisiche, Matematiche e Informatiche, Università di Modena e Reggio Emilia, \\ Via Campi 213/A, 41125 Modena, Italy; vderenzi@unimore.it (V.D.R.); daddato@unimore.it (S.D.) \\ 2 CHOSE-Centre for Hybrid and Organic Solar Energy, Department of Electronics Engineering, University of \\ Rome Tor Vergata, 00133 Rome, Italy; paolo.mariani@uniroma2.it (P.M.); pescetel@uniroma2.it (S.P.); \\ aldo.dicarlo@uniroma2.it (A.D.C.) \\ 3 CNR - Consiglio Nazionale delle Ricerche, Istituto Nanoscienze, Via Campi 213/A, 41125 Modena, Italy; \\ giovanni.bertoni@nano.cnr.it (G.B.); guido.paolicelli@nano.cnr.it (G.P.) \\ 4 IMEM-CNR, Istituto dei Materiali per l'Elettronica ed il Magnetismo, Consiglio Nazionale delle Ricerche, \\ Parco Area delle Scienze 37/ A, 43124 Parma, Italy \\ 5 Dipartimento di Ingegneria E. Ferrari, Università di Modena e Reggio Emilia, Via Vivarelli 10, \\ 41125 Modena, Italy; luca.pasquali@unimore.it \\ 6 IOM-CNR, Istituto Officina dei Materiali, Consiglio Nazionale delle Ricerche, s.s. 14, Km. 163.5 in AREA \\ Science Park, Basovizza, 34149 Trieste, Italy \\ 7 Department of Physics, University of Johannesburg, P.O. Box 524, Auckland Park 2006, South Africa \\ 8 ISM-CNR, Istituto di Struttura della Materia, Consiglio Nazionale delle Ricerche, 00133 Rome, Italy \\ 9 EN \& TECH, Università di Modena e Reggio Emilia, 41125 Modena, Italy \\ check for \\ updates \\ * Correspondence: matteo.caleffi@unimore.it (M.C.); antonio.agresti@uniroma2.it (A.A.)
}

Citation: Caleffi, M.; Mariani, P.; Bertoni, G.; Paolicelli, G.; Pasquali, L.; Agresti, A.; Pescetelli, S.; Di Carlo, A.; De Renzi, V.; D'Addato, S. Ag/MgO Nanoparticles via Gas Aggregation Nanocluster Source for Perovskite Solar Cell Engineering. Materials 2021, 14, 5507. https://doi.org/10.3390/ ma14195507

Academic Editor: Cristobal Voz

Received: 30 August 2021

Accepted: 21 September 2021

Published: 23 September 2021

Publisher's Note: MDPI stays neutral with regard to jurisdictional claims in published maps and institutional affiliations.

Copyright: (c) 2021 by the authors. Licensee MDPI, Basel, Switzerland. This article is an open access article distributed under the terms and conditions of the Creative Commons Attribution (CC BY) license (https:// creativecommons.org/licenses/by/ $4.0 /)$.

\begin{abstract}
Nanocluster aggregation sources based on magnetron-sputtering represent precise and versatile means to deposit a controlled quantity of metal nanoparticles at selected interfaces. In this work, we exploit this methodology to produce $\mathrm{Ag} / \mathrm{MgO}$ nanoparticles (NPs) and deposit them on a glass $/ \mathrm{FTO} / \mathrm{TiO}_{2}$ substrate, which constitutes the mesoscopic front electrode of a monolithic perovskite-based solar cell (PSC). Herein, the Ag NP growth through magnetron sputtering and gas aggregation, subsequently covered with $\mathrm{MgO}$ ultrathin layers, is fully characterized in terms of structural and morphological properties while thermal stability and endurance against air-induced oxidation are demonstrated in accordance with PSC manufacturing processes. Finally, once the NP coverage is optimized, the $\mathrm{Ag} / \mathrm{MgO}$ engineered PSCs demonstrate an overall increase of $5 \%$ in terms of device power conversion efficiencies (up to $17.8 \%$ ).
\end{abstract}

Keywords: nanoparticles; $\mathrm{Ag}$; $\mathrm{MgO}$; perovskite solar cells; gas aggregation nanocluster source; localized surface plasmon resonance

\section{Introduction}

Recently, the development of efficient and low-cost photovoltaic technologies has gained increasing attention from the scientific community for satisfying the thirst for clean and sustainably obtained energy. Amongst third generation photovoltaics, perovskite solar cells (PSCs) stand out due to their power conversion efficiency (PCE), which in the past ten years has been boosted from 3.8\% in 2009 up to $25.6 \%$ in 2021 [1], making them comparable, in terms of PCE, with mature Si solar cells [2]. Such an astonishing result was triggered by the progressive optimization of a PSC structure mainly composed of a perovskite absorber sandwiched between hole and electron selective contacts. Indeed, interfaces between adjacent layers play a crucial role in ruling the device performance and stability, since a charge carrier generated within the perovskite absorber should be efficiently transferred to the selective layers without recombination before being collected at the electrodes [3]. As a matter of fact, the PSC structure should be designed properly 
with the aid of energy band diagrams to avoid barriers at the interfaces, while adjacent layers should be deposited on top of each other by avoiding pinholes or defects due to the poor adhesion, lattice mismatch, solvent incompatibility and/or layer degradation, which occur in post-deposition processing or when the complete devices are in real working conditions and subject to prolonged illumination, prolonged heating, etc.

In this context, interface engineering (IE) has been proposed as a winning strategy for tuning the interface opto-electronic properties, improving the charge dynamics within the device and eventually enhancing the device performance and stability [4]. IE strategies can be classified into three main groups: (i) looking for alternative selective contact materials on the basis of their morphologies and opto-electronic properties [5]; (ii) modification of the perovskite crystalline structure by finely controlling the crystal growing conditions [6], the perovskite precursor solution with possible doping and by considering a 2D perovskite overlayer atop the 3D perovskite absorber [7]; (iii) surface modification of selective contact (mainly involving $\mathrm{TiO}_{2}$ when dealing with the mesoscopic n-i-p structure) [8]. The first strategy needs to completely redesign the device in terms of energy level alignment and to reassess the device lifetime under different stress test conditions. The second strategy requires the optimization of the deposition process for the modified perovskite precursor solution or the fine control of the deposition conditions, as well as an additional production step in the case of a 2D perovskite overlayer. On the contrary, the surface modification of the selective contact where the perovskite layer is deposited could be a viable route for improving the PSC performance without modifying the perovskite precursor composition and eventually its deposition conditions. Moreover, any treatment needed to achieve the selective contact surface modifications (i.e., thermal annealing, UV-ozone, etc.) is only limited by the material constituting the electrode. For example, in the case of mesoscopic PSCs, the usually employed $\mathrm{TiO}_{2}$ layer can be subjected to severe treatment such as high temperature (i.e., in the case of lithium salt treatment) [9], aggressive chemical baths (i.e., $\mathrm{TiCl}_{4}$ treatments) [10] or harsh conditions typically achieved using invasive implantation or deposition techniques (i.e., ion implantation or atomic layer deposition (ALD)) [11]. The mesoscopic structure is thus the best candidate to select for testing IE based on surface modification, even considering that the highest efficiencies ever certified for PSCs were demonstrated by employing a mesoscopic structure [1]. Considering a mesoporous $\mathrm{TiO}_{2}$ $\left(\mathrm{m}-\mathrm{TiO}_{2}\right)$ layer, IE has been clearly demonstrated as an effective strategy for improving the PSC performance and stability when employing several 2D materials [12] such as graphene [13-15] and its derivatives [16-18] as well as transition metal carbides or nitrides commonly known as MXenes $[19,20]$. Notably, the proper 2D materials can be chosen from a wide group (more than 2000 bi-dimensional materials are available), with exceptional opto-electronic properties due to the quantum confinement in the third dimension, that could even be tuned by proper chemical modification or edge modification. Moreover, 2D materials can be produced and dispersed in several solvents by employing a liquid-phase exfoliation (LPE) technique [21] and the production process can be scaled up by employing the recently developed wet-jet milling techniques [22]. However, due to the simplicity of solution-based production processes, $2 \mathrm{D}$ materials are usually in the form of a few layers while the monolayer counterpart, desirable for the ideal charge transport properties, is only achieved by employing costly and time-consuming techniques such as chemical vapor deposition (CVD). The impossibility to finely control the number of the constituting layers for 2D material flakes still represents the main drawback in terms of reproducibility and production process yield. Alternatively to 2D materials, the modification of PSC layers can be achieved by employing nanoparticles (NPs), properly designed in terms of chemical composition and size [23]. Indeed, coupling of NPs with photoactive layers is currently an extremely promising route to enhance device performances in photocatalysis [24] and solar energy conversion applications [25-31]. NP incorporation in photovoltaic (PV) devices has indeed proved successful in increasing their efficiency in a number of cases [27-31], their effectiveness being related to different mechanisms, such as plasmon-enhanced absorption, 
increased optical path length inside the active layer due to the light scattering effect [32,33], hot-electron injections [34-36] and hot spots [37].

In order to be exploited for PV applications, it is important to separate metal NPs from the active layer with an insulating/semiconducting layer, chosen to guarantee: (i) effective hindering of charge recombination at the metal surface; (ii) chemical protection of the metal core, preventing NP aggregation [38] as well as oxidation processes occurring upon device fabrication and functioning, especially when the NPs are exposed to air or other species in the surrounding environment [39]; (iii) thermal stability. On the other hand, the protective layer/shell optical properties and thickness should be chosen to minimize its light absorption and to guarantee the closest possible proximity between the NPs and the active layer.

Furthermore, core-shell NPs allow more flexibility in engineering the optical and electronic properties of the resulting nanostructures, by changing both the shell material and the core-shell size ratio. Recently, improved PSC performance has also been achieved by metal@core-shell NP incorporation at the interface between the photoactive layer (i.e., hybrid organic inorganic lead halide perovskite) and the electron transport layer (ETL) [40-42], showing a remarkable relative increase in the PCE values, from $5 \%$ up to $45 \%$, with respect to the pristine devices.

These promising results were obtained using NPs with different materials [31,42-44] and different geometries [37,45,46]. Among possible metals, silver (Ag) is considered the most promising material for photoactive applications, as it displays a strong absorption in the UV-visible range [47] and a lower manufacturing cost compared with its nearest competitors, gold $(\mathrm{Au})$ and platinum $(\mathrm{Pt})$. As far as shell materials are concerned, most of the studies related to $\mathrm{Ag}$ NPs report the use of $\mathrm{TiO}_{2}$ or $\mathrm{SiO}_{2}$ shells, and chemical wet methods for both NP@core-shell synthesis and the subsequent deposition [48]. Though chemical synthesis guarantees high production outputs and scalability, in some cases, there may be limits to the choice of protective materials and their thickness. For instance, $\mathrm{MgO}$ is a very promising alternative shell material due to its wide energy gap $\left(E_{g}=6 \mathrm{eV}\right)$ [49], low absorption coefficient in the UV-Vis region, outstanding chemical inertness, high temperature stability and efficacy in shielding metal NPs from the surrounding environment [50]. Despite these characteristics, proper $\mathrm{Ag} @ \mathrm{MgO}$ NPs are notably difficult to obtain by chemical synthesis in liquid solution, due to the incompatibility between Ag NPs and MgO synthesis techniques and the high tendency of $\mathrm{MgO}$ to aggregate and form thermodynamically stable films. These difficulties have to date hindered the use of Ag@MgO NPs in photovoltaic applications. A recent study [51] highlights the possibility for a combined use of Au NPs and a $\mathrm{MgO}$ passivation film, in particular by incorporating $\mathrm{Au} \mathrm{NPs}$ into an $\mathrm{m}-\mathrm{TiO}_{2}$ layer and depositing a $\mathrm{MgO}$ film on the Au NP-modified mesoporous $\mathrm{TiO}_{2}$ via wet spinning and pyrolysis of magnesium salt. The study demonstrates that the combination of metal NPs and magnesia is an effective and functional blend that can be exploited to design hybrid organic-inorganic perovskite photovoltaic devices with enhanced characteristics, reaching a PCE improvement of about $34 \%$ with respect to the pristine device, therefore validating the potential of $\mathrm{MgO}$ as outstanding material for $\mathrm{PV}$ applications. In addition, $\mathrm{MgO}$ has been used as a hole-blocking layer between $\mathrm{TiO}_{2}$ ETL and the perovskite, improving the overall performances of solar devices by about $30 \%$ in terms of PCE enhancement [52].

In this work, we exploit the extremely versatile and clean physical synthesis methodology to introduce $\mathrm{Ag} / \mathrm{MgO}$ nanoparticles in a mesoscopic perovskite-based solar device, investigating their in situ properties and their overall effect on the device performance. In more detail, Ag NPs are grown through magnetron sputtering and gas aggregation, deposited in a high vacuum chamber on a glass $/ \mathrm{FTO} / \mathrm{c}-\mathrm{TiO}_{2} / \mathrm{m}-\mathrm{TiO}_{2}$ substrate. The protective $\mathrm{MgO}$ ultrathin film is introduced with sequential layer deposition [53,54] or codeposition methods [55,56], by thermally evaporating $\mathrm{Mg}$ in an oxygen environment [50], inside an ultra-high vacuum (UHV) chamber. The system morphology and structure are then thoroughly characterized by means of X-ray photoemission spectroscopy (XPS), scanning electron microscopy (SEM), atomic force microscopy (AFM) and transmission 
electron microscopy (TEM), while its UV-Vis optical properties are investigated by means of polarized reflectivity and transmissivity measurements. Subsequent deposition of the perovskite active layer and fabrication of the final devices allow us to test the cell electrical performance, showing an improvement in current densities in the case of $1.5 \% \mathrm{Ag} / \mathrm{MgO}$ NP loading. As the main result, this study proves the feasibility of physical deposition methods of plasmonic NPs for possible application in PSCs. It therefore paves the way to explore different combinations of metal cores and protective shell or layer materials, aiming for the fabrication of solar devices with increased current density and efficiency.

\section{Materials and Methods}

Mesoporous titania paste (30 NRD), formamidinium iodide (FAI) and methylammonium bromide (MABr) were purchased from GreatCell SolarDyesol ${ }^{\circledR}$. Lead(II) iodide $\left(\mathrm{PbI}_{2}\right)$, and lead(II) bromide $\left(\mathrm{PbBr}_{2}\right)$ were purchased from TCI. Cesium iodide (CsI) was purchased from $\mathrm{GmbH}$. 2,20,7,70-tetrakis-(N,N-dip-methoxyphenylamine)9,9'-spirobifluorene (spiroOMeTAD) was purchased from Borun, and cobalt(III) FK209 was purchased from Lumtec.

Titanium(IV) isopropoxide (TTIP), diisopropoxytitanium bis(acetylacetonate) (Ti(AcAc) 2 ), acetyl acetone (AcAc), acetylacetone, ethanol (EtOH), 2-propanol (IPA), acetone, dimethylformamide (DMF), dimethyl sulfoxide (DMSO), acetonitrile (ACN), tert-butylpyridine $(\mathrm{tBP})$, chlorobenzene $(\mathrm{CB})$ and lithium bis(trifluoromethanesulfonyl)imide (Li-TFSI) were purchased from Sigma-Aldrich.

Patterned fluorinated doped tin oxide (FTO)-coated glasses (Pilkington, $7 \Omega \mathrm{cm}^{-1}$ ) were washed with deionized water and soap, then cleaned first with a cycle of ultrasonic bath in acetone, then with ethanol, for $10 \mathrm{~min}$ at each stage. The compact $\mathrm{TiO}_{2}$ $\left(\mathrm{c}-\mathrm{TiO}_{2}\right.$ ) layer (around $50 \mathrm{~nm}$ ) was deposited by a spray pyrolysis technique at $460{ }^{\circ} \mathrm{C}$. The sprayed solution consists of $0.16 \mathrm{M} \mathrm{Ti}(\mathrm{AcAc})_{2}$ and $0.4 \mathrm{M}$ AcAc in EtOH. Subsequently, the $\mathrm{TiO}_{2}$ mesoporous $\left(\mathrm{m}-\mathrm{TiO}_{2}\right.$ ) solution was prepared using $\mathrm{m}-\mathrm{TiO}_{2}$ paste $(30 \mathrm{NRD})$ in $\mathrm{EtOH}$ $(1: 5 \mathrm{wt} / \mathrm{wt})$. The resulting $\mathrm{m}-\mathrm{TiO}_{2}$ solution was deposited on the substrate by spin coating at $3000 \mathrm{rpm}$ for $20 \mathrm{~s}$ with subsequent annealing in air for $30 \mathrm{~min}$ at $480^{\circ} \mathrm{C}$, resulting in a mesoporous layer with thickness of $120 \mathrm{~nm}$ and roughness around $30-40 \mathrm{~nm}$. The engineered mesoscopic substrates were then transferred in an inert environment (nitrogen-filled glovebox) to complete the device realization.

The deposition of $\mathrm{Cs}_{0.05}\left(\mathrm{MA}_{0.17} \mathrm{FA}_{0.83}\right)_{95} \mathrm{~Pb}\left(\mathrm{I}_{0.83} \mathrm{Br}_{0.17}\right)_{3}$ was performed in nitrogen atmosphere following the antisolvent procedure, as detailed in our previous work [57-59]. A solution of $\mathrm{PbI}_{2}, \mathrm{PbBr}_{2}, \mathrm{MABr}, \mathrm{FAI}$ and $\mathrm{CsI}$ in a solvent mixture of DMF and DMSO with a 4:1 ratio (v:v), respectively, was deposited by spin coating on top of the aforementioned substrates, following a sequential program at 1000 and $5000 \mathrm{rpm}$ for 10 and $30 \mathrm{~s}$, respectively. During the second spin stage, $150 \mu \mathrm{L}$ of chlorobenzene was quickly dropped on the rotating substrate at $7 \mathrm{~s}$ to the end of the program. Then, the substrates were immediately annealed at $100{ }^{\circ} \mathrm{C}$ for $1 \mathrm{~h}$. Afterwards, spiro-OMeTAD $\left(73.5 \mathrm{~g} \cdot \mathrm{L}^{-1}\right.$ in CB solution doped with TBP $\left.\left(26.7 \mu \mathrm{L} \cdot \mathrm{mL}^{-1}\right)\right)$, LiTFSI $\left(16.6 \mu \mathrm{L} \cdot \mathrm{mL}^{-1}\right)$ and a Co complex $\left(7.2 \mu \mathrm{L} \cdot \mathrm{mL}^{-1}\right)$ were spin coated at $2000 \mathrm{rpm}$ for $20 \mathrm{~s}$. The devices were then finalized by thermally evaporating a gold counter electrode, with a thickness of around $100 \mathrm{~nm}$, in high vacuum conditions (around $10^{-6} \mathrm{mbar}$ ), with an active area of $0.1 \mathrm{~cm}^{2}$, determined by a black mask applied on the device backside.

The flat $\mathrm{TiO}_{2}$ substrate (made of $\mathrm{SiO}_{2} / \mathrm{TiO}_{2}$ ) was produced at a high deposition rate (tens of nm per minute) by reactive DC-magnetron sputtering from metal targets (Ti) on a $\mathrm{SiO}_{2}$ substrate. The overall synthesis and deposition of $\mathrm{Ag} / \mathrm{MgO}$ NPs was executed inside a UHV chamber connected to a nanocluster source (a complete description of the system can be found elsewhere in previous works [60]). The Ag NP deposition was performed using a nanocluster source, composed of a magnetron (NC200U, Oxford Applied Research), connected with a quadrupole mass filter (QMF). The deposition of $\mathrm{MgO}$ was realized by thermally evaporating $\mathrm{Mg}$ in an $\mathrm{O}_{2}$ atmosphere with similar procedures used elsewhere [50,61]. The deposition rate of $\mathrm{Ag}$ and $\mathrm{Mg}$ was carefully monitored and tuned using a quartz microbalance. For the experiments reported in this work, Ag NPs were 
produced with a magnetron discharge power $\mathrm{P}=50 \mathrm{~W}$ and Ar flow value set at $\mathrm{f}=60 \mathrm{sccm}$. The $\mathrm{O}_{2}$ partial pressure was adjusted in order to obtain the right proportion of $\mathrm{Mg}$ to $\mathrm{O}_{2}$ to form $\mathrm{MgO}$. Typical $\mathrm{O}_{2}$ partial pressure was $\mathrm{P}_{\mathrm{O} 2}=3 \times 10^{-7}$ mbar. The Ag NP deposition rate, expressed in thickness of a continuum film with bulk $\mathrm{Ag}$ density per unit time, varied between 1 and $0.3 \AA / \mathrm{min}$. MgO deposition rate varied between 10 and $12 \AA / \mathrm{min}$. The amount of deposited Ag NPs is given in this work in terms of surface coverage and for $\mathrm{MgO}$ in terms of nominal thickness of an equivalent continuous film with the same density as bulk rock salt $\mathrm{MgO}$. The size distribution of the deposited nanoparticles was estimated ex situ with SEM and TEM. The prepared samples were characterized by SEM using a Nova Nano SEM450 (FEI Company-Bruker Corporation,5350 NE Dawson Creek Drive Hillsboro, Hillsborough, OR, USA).

The SEM column is equipped with a Schottky field-emission gun (SFEG) and it can achieve a resolution of $1.4 \mathrm{~nm}$ in low-voltage $(1 \mathrm{kV})$ operation. The TEM measurements were carried out with a TALOS F200S G2 (Thermo-Fisher Scientific,168 Third Avenue Waltham, MA, USA) equipped with a Schottky Field Emitter $(80-200 \mathrm{keV})$ operating in TEM and STEM mode, and a double silicon drift detector (SDD) for energy dispersive X-ray spectroscopy (EDXS). For a better visualization and quantification of the EDXS chemical maps (especially for the low $\mathrm{Mg}$ signal), we performed a denoising of the spectra based on principal component analysis (PCA) [62]. The average height distribution of NP films was estimated with AFM (NTEGRA AURA model, NT-MDT).

Thermal annealing for the evaluation of the stability of NPs was performed ex situ and verified with XPS using $\mathrm{Al} \mathrm{K} \alpha$ photons and a hemispherical electron analyzer in normal emission geometry. The optical measurements were performed ex situ using a linearly polarized $s$ radiation, with an angle of $45^{\circ}$ between sample and incident beam. The UV-Vis experiment system architecture was composed of an Ocean Optics DH-20000-BAL light source, the emitted radiation wavelength was between 200 and $1050 \mathrm{~nm}$; the polarizers and the HR4000CG-UV-NIR grating monochromator were purchased from Ocean Optics and furnished with CCD detectors. The J-V characterization of the PSCs was performed with a customized PXI (National Instruments)-based platform (Arkeo). The instrumental setup was composed of a 4-channel source-meter (NI PXIe 4141) and a power supply (NI PXIe 4112) used to deliver high-power white LED (Bridgelux-50C10K0, 5000 Kelvin). The 1 SUN $\left(100 \mathrm{~mW} \cdot \mathrm{cm}^{-2}\right)$ equivalent incident power was then calibrated with a certified reference Si cell (RERA Solutions RR-1002) through the Mismatch Factor [63,64]. IPCE spectra acquisition were realized using a homemade setup with a monochromator (Newport, mod. 74000, Newport Corporation 1791 Deere Avenue Irvine, CA, USA) coupled with a xenon lamp (Oriel Apex, Newport Corporation 1791 Deere Avenue Irvine, CA, USA) and a source meter (Keithley, mod. 2420), controlled by a home-made LabVIEW program for acquiring spectra [65].

Figure 1 displays a schematic representation of the experimental steps adopted for the realization of every layer of the PSCs and the physical deposition of $\mathrm{Ag} / \mathrm{MgO} \mathrm{NPs}$, along with the corresponding energy band diagram. 
a Deposition of $\mathrm{C}-\mathrm{TiO}$ : and $\mathrm{m}-\mathrm{TiO}_{2}$ on $\mathrm{FTO}$ Glass b Deposition of Ag NPs and MgO

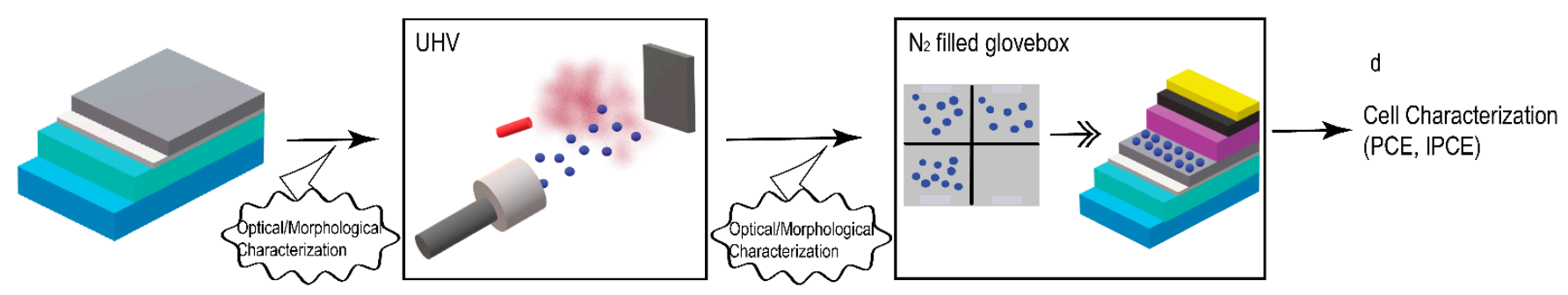

Deposition of perovksite, Spiro-OMeTAD,

and Au electrode

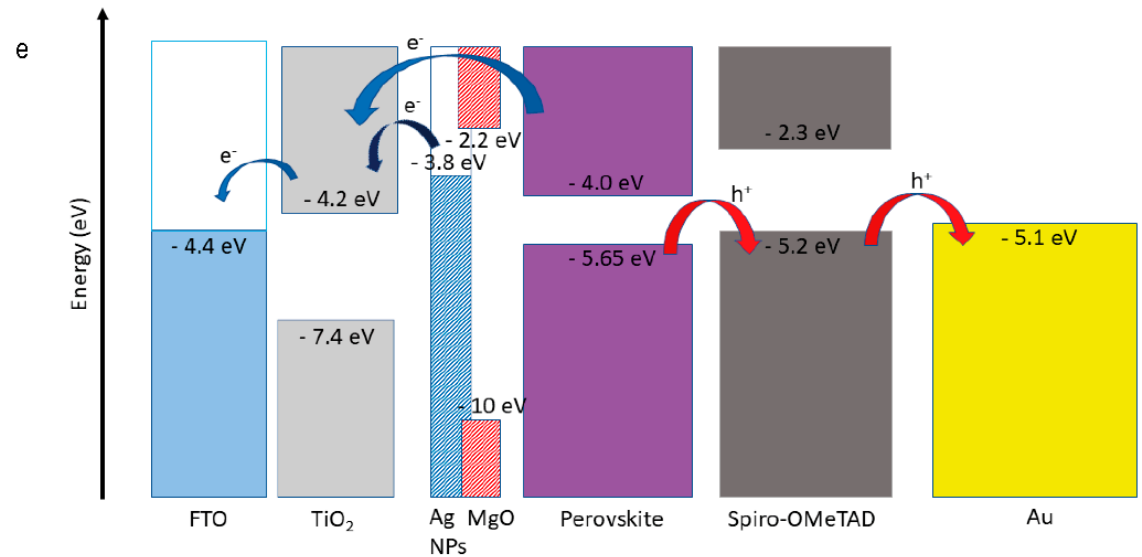

Figure 1. (a) Representation of the initial substrate, from bottom to the top: conductive glass substrate (blue) (2.2 $\mathrm{mm})$ covered with an FTO layer (aquamarine) (around $700 \mathrm{~nm}$ ), compact $\mathrm{TiO}_{2}$ layer (light gray) (around 50 nm), mesoporous $\mathrm{TiO}_{2}$ layer (gray) (around $150 \mathrm{~nm}$ ). (b) Scheme of the NP (dark blue) synthesis and deposition with $\mathrm{MgO}$ (red) on top of the previously realized $\mathrm{m}-\mathrm{TiO}_{2}$ layer. (c) Top view scheme of the experimental device until the $\mathrm{m}-\mathrm{TiO}_{2}$ layer (see the left part of scheme c), containing four independent cells, three of them with NPs and one used as the reference cell, while the right part of scheme $\mathrm{c}$ represents the addition of the perovskite layer (violet) (around $400 \mathrm{~nm}$ ), Spiro-OMeTAD layer (black) (250 nm) and gold layer (yellow) (around $100 \mathrm{~nm}$ ); NPs are localized at the interface between the perovskite and mesoporous $\mathrm{TiO}_{2}$ layer. The dimensions of each layer displayed here are not to scale. (d) Final step of characterization of the engineered solar devices. (e) Energy band diagram of the device. The work function values for FTO, $\mathrm{TiO}_{2}$ have been taken from references $[66,67]$. The highest occupied molecular orbital (HOMO) and lowest unoccupied molecular orbital (LUMO) levels for perovskite have been taken from reference [68]. The energy band edge positions for Spiro-OMeTAD have been taken from reference [69]. The energy band values for Ag NPs and MgO are taken from reference [70] and [71], respectively. The depicted energy values are relative to the vacuum level. Blue and red arrows show the direction of electron and hole motion, respectively.

\section{Results and Discussion}

The formation of $\mathrm{Ag} / \mathrm{MgO}$ NPs was firstly assessed by TEM, depositing $5 \mathrm{~nm}$ (nominal thickness) Ag nanoclusters and $0.8 \mathrm{~nm} \mathrm{MgO}$ via co-deposition [61] on a TEM grid. The main information of the NP structure was obtained from a high-resolution, bright-field TEM image of a single NP, as shown in Figure 2a. Lattice fringes are visible across almost all the particle, although in some areas they are confused, probably because of the contributions from both the Ag core and $\mathrm{MgO}$ protective layer in an almost spherical NP. In particular, in the region delimited by the white square, the fringes can be assigned to an icosahedral-type structure in 2-fold orientation, as can be seen from the simulation in Figure 2c. Ag (111) planes are quite evident (see the fast Fourier transform (FFT) image in Figure 2b), and the analysis gives an interplanar distance of $0.238 \mathrm{~nm}$. The occurrence of the icosahedral shape in physically synthesized face-centered cubic (fcc) metals clusters and NPs - such as bare $\mathrm{Ag}$, Ni and FePt-has been previously reported [50,60,61]. The physical reason for this arrangement has been ascribed to the kinematics of the cluster formation [72-75] in the aggregation region of the NP source, in particular to the cooling velocity during the collision process with the inert gas atoms. The cluster freezing favors formation of multi- 
twinned domains in the nascent nanocrystal, which gives rise to metastable structures deviating from the Born-Wulff construction [72-75]. It can therefore be concluded that the structure of the Ag core, consisting of a multi-twinned McKay icosahedron [73], is preserved during the formation of the $\mathrm{MgO}$ film. In the top-right region of the NP, image reflections are visible with a corresponding interplanar distance $\mathrm{d}=0.213 \mathrm{~nm}$, which can be assigned to (200) $\mathrm{MgO}$ planes. This confirms that $\mathrm{MgO}$ covers, at least partially, the Ag core.
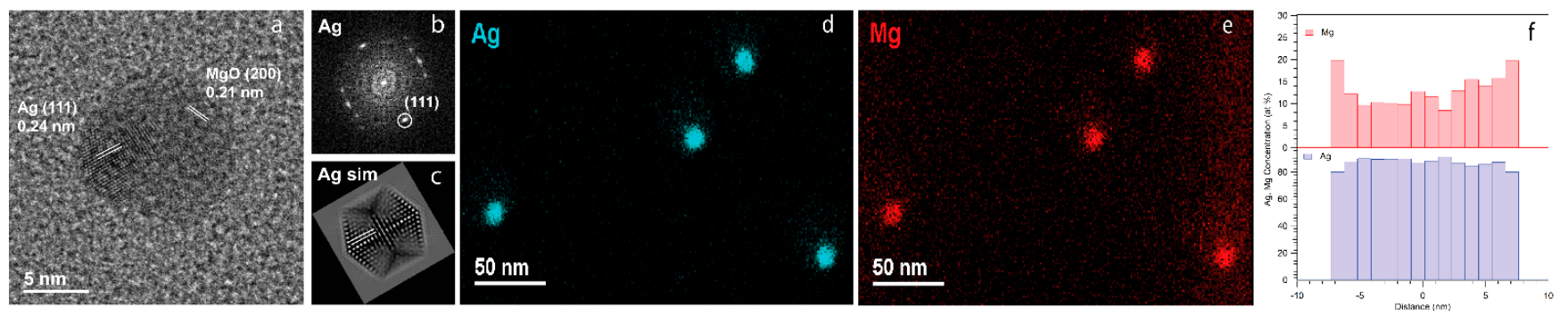

Figure 2. (a) Bright-field HRTEM image of an $\mathrm{Ag} / \mathrm{MgO} \mathrm{NP}$. The lattice fringes from $\mathrm{Ag}$ (111) planes are shown in the left part of the NP. Planes assigned to MgO (200) are shown in the top right of the NP image. (b) FFT image from the Ag domain, and (c) simulated image from an Ag ideal icosahedral domain oriented along the 2-fold axis. (d) EDXS map of Ag-L edge intensity (cyan), (e) EDXS map of Mg-K edge intensity (red). (f) EDXS profile for Ag and Mg content (atomic \%) from a single NP.

In Figure 2d, the EDXS map corresponding to the Ag-L (cyan) edge clearly reveals a few rounded Ag NPs, whose diameter is estimated to be around $(10.0 \pm 0.6) \mathrm{nm}$. The $\mathrm{Mg}$ map (Figure 2e) provides evidence of the preferential adsorption of $\mathrm{MgO}$ on top of Ag NPs, while the EDXS line profile from a single NP reported in Figure $2 \mathrm{f}$ shows that $\mathrm{Mg}$ has a higher concentration at the edge of the NP, as previously found in similar systems [61] and as expected by a thin capping layer.

It has been demonstrated that the morphological properties of physically synthesized NPs may be significantly influenced by the substrate on which they are deposited [76,77]. For this reason, it is important to fully characterize the $\mathrm{Ag} / \mathrm{MgO}$ directly on the technologically relevant substrate, i.e., the glass $/ \mathrm{FTO} / \mathrm{c}-\mathrm{TiO}_{2} / \mathrm{m}-\mathrm{TiO}_{2}$ (where c- $\mathrm{TiO}_{2}$ is a compact titanium dioxide layer, while $\mathrm{m}-\mathrm{TiO}_{2}$ is the mesoporous top layer) used in fabrication of PSCs [78]. In this case, the MgO capping layer was sequentially deposited on top of NPs, following the procedures given in reference [50]. The effectiveness of this approach relies on the low sticking coefficient of $\mathrm{MgO}$ on $\mathrm{TiO}_{2}$, as compared to that on $\mathrm{Ag}$. This has been preliminarily proved through XPS; after a nominal deposition of $6 \AA \mathrm{MgO}-$ as evaluated by a calibrated quartz microbalance - the amount of $\mathrm{Mg}$ deposited on a bare $\mathrm{TiO}_{2}$ substrate without NPs-as estimated from XPS quantitative analysis (see Figure S1 in Supplementary Materials)—was $0.1 \AA$, indicating a $\mathrm{MgO}$ sticking coefficient on $\mathrm{TiO}_{2}$ substrate of less than $2 \%$. This finding safely allows us to consider the $\mathrm{MgO}$ capping layer to cover only the deposited Ag NPs, for relatively low NP coverages, while leaving the bare $\mathrm{TiO}_{2}$ substrate essentially unaffected.

The morphology of $\mathrm{Ag} / \mathrm{MgO}$ NPs deposited on $\mathrm{TiO}_{2}$ substrates was investigated by SEM. As shown in Figure 3a, the substrate top layer is an $\mathrm{m}-\mathrm{TiO}_{2}$ film characterized by a mesoporous morphology, with pore dimensions of a few tens of nanometers, i.e., comparable with the NP diameter. For this reason, we acquire SEM images using the backscattered electron signal (BSE), which, as shown in Figure $3 \mathrm{~b}$,e for 1.5\% and 10\% coverage, respectively, allows us to single out the heavier Ag cluster $(Z=49)$ from lighter $\mathrm{TiO}_{2}$ substrate and to statistically analyze their size distribution [79], as shown in Figure 3c. The obtained NP size distribution is fitted with the log-normal function described by $\mathrm{O}^{\prime}$ Grady et al. [80], finding an average NP diameter $\mathrm{d}=8 \mathrm{~nm}$, with an FWHM of $7 \mathrm{~nm}$ for the $1.5 \%$ coverage case. For higher coverages, the complicated morphology of the mesoporous films may introduce an overestimation of the NP dimensions, as NPs which 
are actually on different terraces may improperly appear as single larger aggregates. For this reason, a more thoroughly analysis for $10 \%$ coverage was performed using a flat, but chemically equivalent, $\mathrm{TiO}_{2}$ substrate, grown on $\mathrm{SiO}_{2}$, as shown in Figure 3d. The resulting size distribution gives $d=13 \mathrm{~nm}$ and FWHM increases to $17 \mathrm{~nm}$, for the $10 \%$ coverage (Figure 3f).
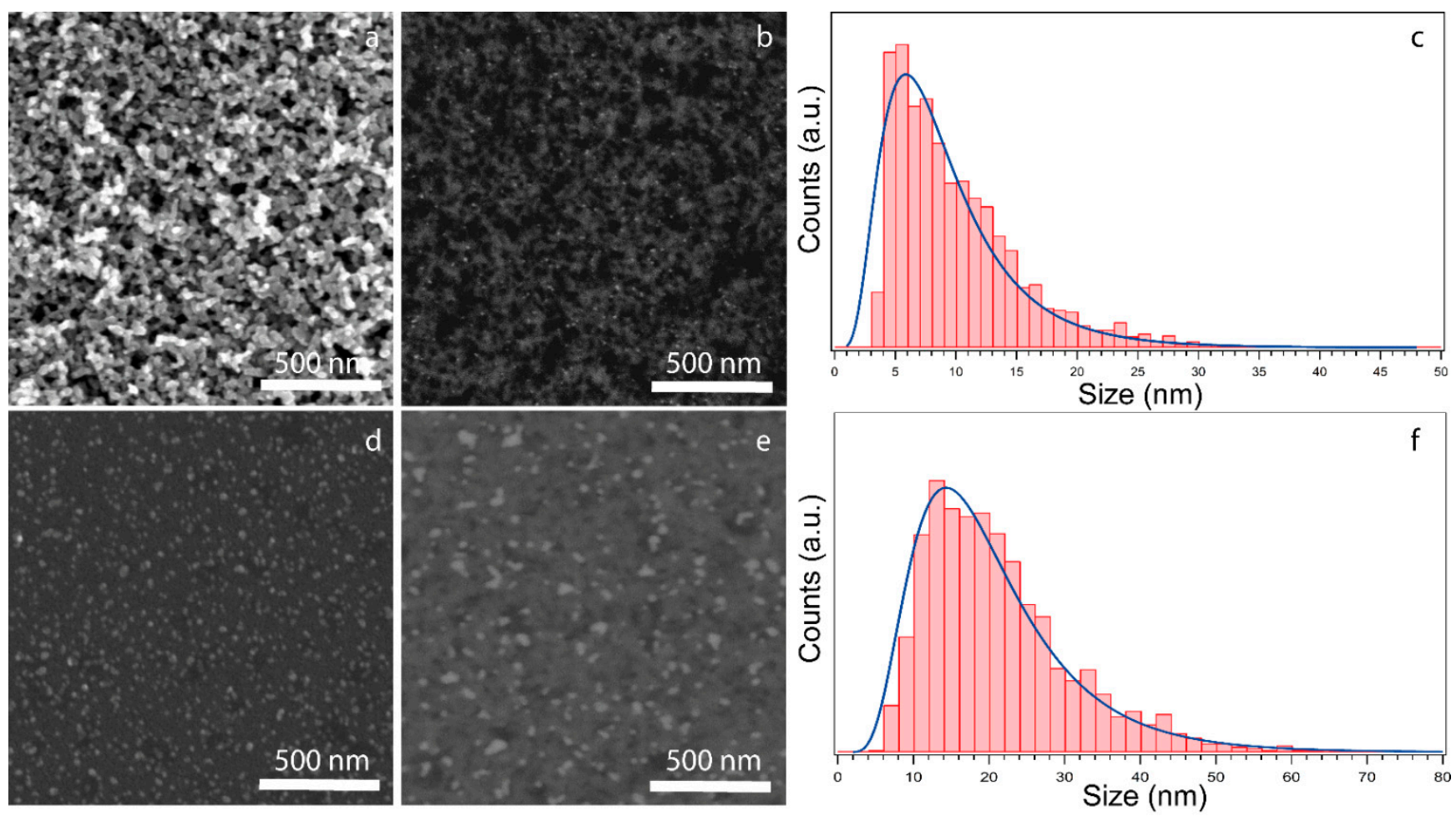

Figure 3. (a) SE SEM image of a typical mesoporous $\mathrm{TiO}_{2}$ sample, (b) BSE SEM image of $1.5 \%$ coverage in $\mathrm{Ag} / \mathrm{MgO}$ sample on $\mathrm{m}-\mathrm{TiO}_{2}$, (c) size distribution resulting from analysis of Figure $3 \mathrm{~b}$ corresponding to $1.5 \%$ NP coverage, (d) SE SEM image of $\mathrm{Ag} / \mathrm{MgO} \mathrm{NPs}$ with $10 \%$ coverage on a flat $\mathrm{TiO}_{2}$ substrate, (e) BSE SEM image of $10 \%$ coverage of $\mathrm{Ag} / \mathrm{MgO} \mathrm{NPs}$ on $\mathrm{m}-\mathrm{TiO}_{2}$, (f) size distribution resulting from analysis of Figure $3 \mathrm{~d}$.

Deposition on the flat $\mathrm{TiO}_{2}$ substrate also allows us to investigate the NP height distribution by means of AFM topography. In Figure 4, the topography of the Ag/MgO on $\mathrm{TiO}_{2}$ is reported (Figure $4 \mathrm{a}$ ), along with the relative height distribution (Figure $4 \mathrm{~b}$ ). The latter appears clearly as bimodal and it is fitted with two log-normal components: the first component (peak 0) can be ascribed to the surface roughness of $\mathrm{TiO}_{2}$ film bare areas with an average height value $\left\langle\mathrm{h}_{0}>=3\right.$ and FWHM $=2 \mathrm{~nm}$ (as shown in Figure S2, the bare $\mathrm{TiO}_{2}$ substrate is characterized by a surface roughness of $3 \mathrm{~nm}$ ), while the second component (peak 1) corresponds to the NP height distribution, with mean value $<\mathrm{h}_{1}>=7.3$ and FWHM $=2 \mathrm{~nm}$ (Figure $4 \mathrm{~b}$ ). A fair estimate of the average NP height can be given by subtracting the average values of the two components, resulting in a value $<\mathrm{h}>=4 \mathrm{~nm}$ (see also references [81,82]).

Assuming that the NP height does not strongly depend on coverage, for relatively low coverages, and combining SEM and AFM information on size (d) and height (h) distribution, respectively, we can estimate the $\mathrm{Ag} / \mathrm{MgO} \mathrm{NP}$ aspect ratio with the formula $\mathrm{AR}=\mathrm{d} / \mathrm{h}$. The mean $\mathrm{AR}$ value varies from $\sim 2$ to 3 , upon increasing coverage from $1.5 \%$ to $10 \%$; the origin of this flat shape may be associated with both shape deformation as a result of the interaction of the NPs with the surface $[81,82]$ and the formation of small aggregates [50]. 


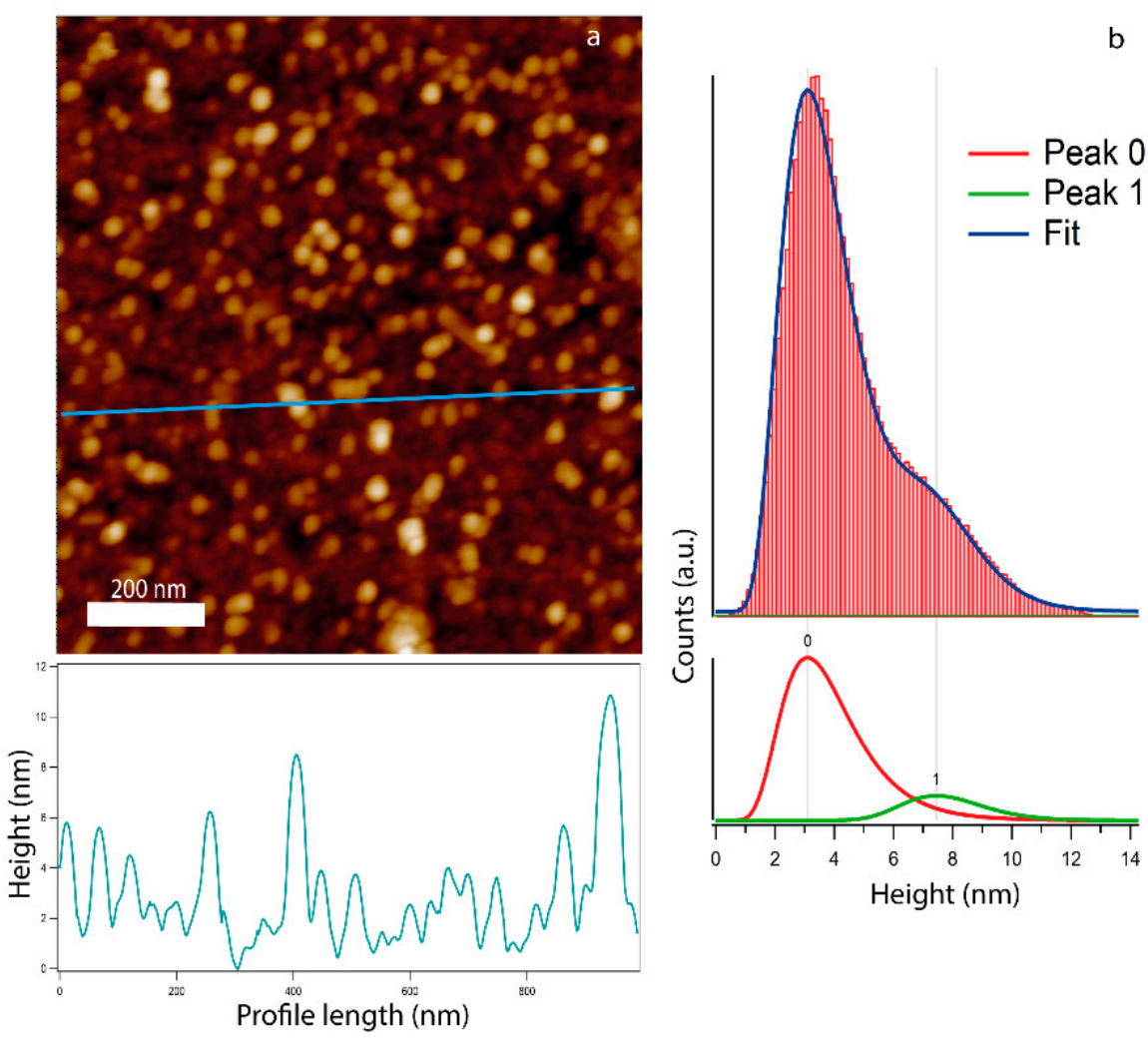

Figure 4. (a) AFM image of $\mathrm{Ag} / \mathrm{MgO} \mathrm{NPs}$ on flat $\mathrm{TiO}_{2}$ substrate with a profile line at the bottom, (b) AFM analysis of the resulting height histogram distribution, red curve (peak 0) is the fitting component corresponding to the substrate roughness, while the green curve (peak 1) is the fitting component corresponding to the height distribution of the $\mathrm{Ag} / \mathrm{MgO} \mathrm{NPs}$.

The thermal stability of the $\mathrm{Ag} / \mathrm{MgO}$-engineered substrates is an extremely relevant aspect to be considered when photovoltaic applications are pursued. Indeed, a temperature as high as $100{ }^{\circ} \mathrm{C}$ is reached during the formation of the perovskite layer on top of the functionalized substrate; moreover, the environmental heat generated during PSC working conditions may also increase the temperature well above room temperature [83]. We have therefore tested the thermal stability of the functionalized substrate by means of XPS, upon annealing up to $\mathrm{T}=150^{\circ} \mathrm{C}$ in UHV (base pressure $5 \times 10^{-10} \mathrm{mbar}$ ). For this experiment, a glass $/ \mathrm{FTO} / \mathrm{c}-\mathrm{TiO}_{2} / \mathrm{m}-\mathrm{TiO}_{2}$ substrate was functionalized with $15 \%$ coverage of $\mathrm{Ag} \mathrm{NPs}$ and covered with $1 \mathrm{~nm}$ (nominal thickness) of $\mathrm{MgO}$. It was exposed to air for $10 \mathrm{~min}$ during the transfer to another UHV system, equipped with a sample heater and an XPS instrument. Figure 5 shows the $\mathrm{Ag} 3 \mathrm{~d}$ core level spectra acquired at room temperature and after annealing at $\mathrm{T}=100{ }^{\circ} \mathrm{C}$ and $\mathrm{T}=150^{\circ} \mathrm{C}$ for $20 \mathrm{~min}$, respectively. A spectrum taken on a bare Ag NP sample after exposure to air for $30 \mathrm{~min}(\mathrm{OX})$ at room temperature is also shown for comparison. In the case of bare Ag NPs, air exposure completely quenches the plasmonic loss at $372 \mathrm{eV}$, while the $\mathrm{Ag} 3 \mathrm{~d}$ peaks become broader. In the case of $\mathrm{Ag} / \mathrm{MgO}$ NPs instead, the plasmonic loss is clearly visible, while no oxidized component appears, indicating that $\mathrm{MgO}$ is positively acting as a proper capping material in protecting the metal core from oxidation. Furthermore, upon annealing, the $\mathrm{Ag}$ plasmonic feature is preserved, proving that the functionalized substrates are stable up to $150{ }^{\circ} \mathrm{C}$, with $\mathrm{Ag}$ in its metallic phase. In addition, the $\mathrm{Ag}$ and $\mathrm{Mg}$ core level intensities remain essentially constant during the annealing, showing that the system is stable in this temperature range. 


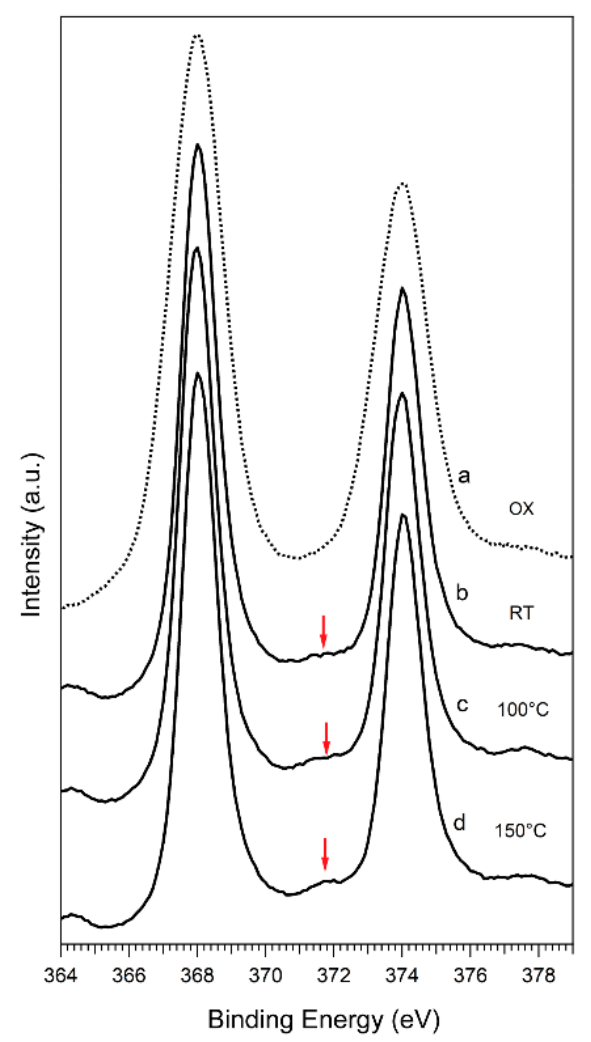

Figure 5. XPS (a) Ag 3d core level of bare Ag NPs after air exposure, (b) Ag 3d core levels at room temperature (RT), (c) Ag $3 \mathrm{~d}$ core levels at $100{ }^{\circ} \mathrm{C}$ and (d) $\mathrm{Ag} 3 \mathrm{~d}$ core level at $150{ }^{\circ} \mathrm{C}$. The system used was glass $/ \mathrm{FTO} / \mathrm{c}-\mathrm{TiO}_{2} / \mathrm{m}-\mathrm{TiO}_{2} / \mathrm{Ag} \mathrm{NPs} / \mathrm{MgO}$. The red arrows highlight the plasmonic features.

The system optical response for different NP coverages is investigated by measuring its UV-Vis reflectivity $R(\lambda)$ and transmissivity $T(\lambda)$, with s-polarized light and beam incidence of $45^{\circ}$ with respect to the surface normal. Measurements are performed on samples subdivided into four areas, on top of which four single and electrically independent cells are successively grown in the same conditions. Typically (Figure 1c (left)), three cells were functionalized with the same NP amount, while the fourth was kept pristine by proper masking, and serves as a reference. In the upper panel of Figure 6a we show the UV-Vis optical loss $\mathrm{L}$, defined as $\mathrm{L}=1-(\mathrm{T}+\mathrm{R})$ as a function of the wavelength, for samples corresponding to NP coverage of $1.5 \%, 3.5 \%$ and $9 \%$, respectively. For each coverage, the spectrum $\mathrm{L}_{\text {sub }}$ of the corresponding glass $/ \mathrm{FTO} / \mathrm{c}-\mathrm{TiO}_{2} / \mathrm{m}-\mathrm{TiO}_{2}$ pristine substrate is shown for comparison.

The lower panel (Figure $6 \mathrm{~b}$ ) reports the differential optical loss, i.e., $\Delta \mathrm{L}=\mathrm{L}-\mathrm{L}_{\text {sub }}$.

For $1.5 \%$ coverage, $\Delta \mathrm{L}$ is characterized by a broad feature peaking at $\lambda \sim 420 \mathrm{~nm}$, together with a tail extending to a higher wavelength, up to $\lambda \sim 700 \mathrm{~nm}$. For higher coverages, the overall $\Delta \mathrm{L}$ intensity progressively increases, the main peak slightly red shifting and becoming broader while the high-wavelength tail rises [84]. The origin of these features and their dependence on coverage can be rationalized considering that the optical loss is given by two contributions, i.e., the layer absorbance (A) and the scatter (S), the latter accounting for light diffusion induced by surface roughness [85]. The main peak observed at $\lambda=430 \mathrm{~nm}$ can be assigned to the Ag NP localized surface plasma resonance (LSPR) absorbance while the broad tail can be attributed to an enhancement in light diffusion (decreasing at longer wavelengths [86]), caused by NP-induced increasing surface roughening. 

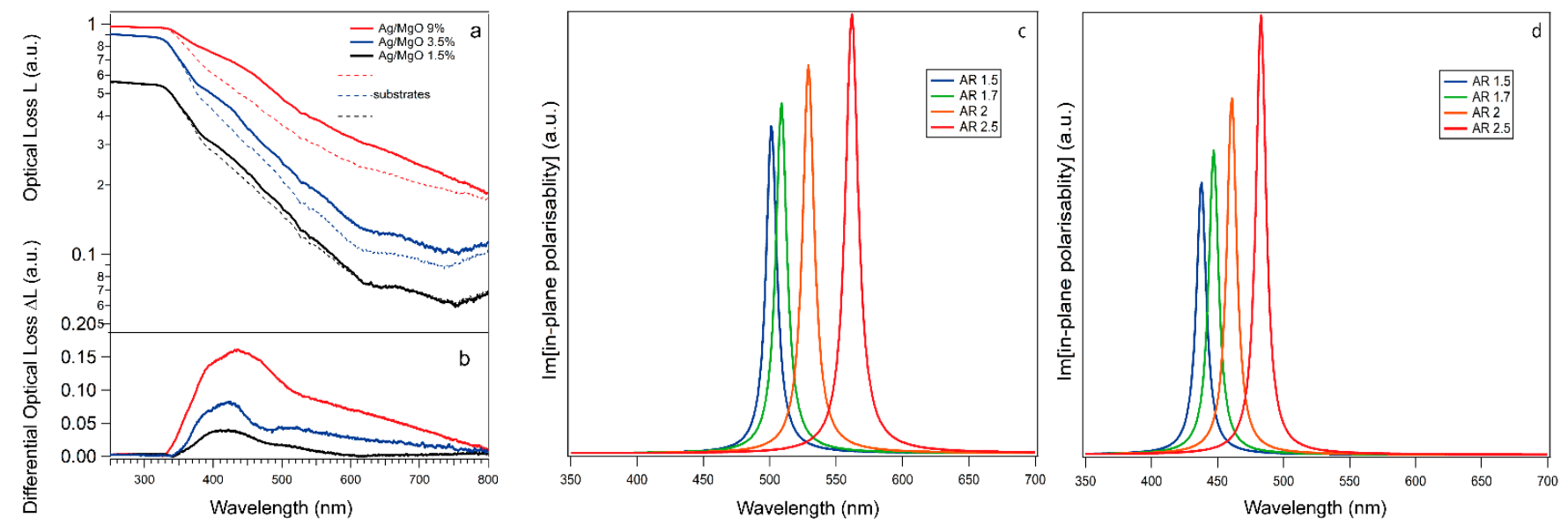

Figure 6. (a) Optical loss spectra of Ag/MgO NPs at different coverages levels. (b) Differential optical loss spectra of samples with different coverages of $\mathrm{Ag} / \mathrm{MgO}$ NPs. The differences in signal intensity of $\mathrm{L}_{\text {sub }}$ (and therefore the corresponding $\mathrm{L}$ ) for different samples may arise from small variations in contaminants (e.g., carbon), humidity and roughness. (c) The imaginary part of the calculated in-plane polarizability for Ag NPs having different aspect ratios embedded in a MgO matrix with refractive index $n=1.7$. (d) The imaginary part of the calculated in-plane polarizability for Ag NPs having different aspect ratios embedded in a $\mathrm{MgO}$ matrix with refractive index $\mathrm{n}=1.4$. Only the in-plane component of the polarizability has been computed due to the s-polarization of the light beam.

It is well known that the NP optical absorption response is highly influenced by nanoparticle shape—especially their aspect ratio (AR) [87]—as well as by the dielectric properties of the embedding material, while it is fairly independent from NP size, at least for diameters in the $5-40 \mathrm{~nm}$ range [88]. For bare, spherical Ag NPs, the LSPR is localized at $390 \mathrm{~nm}$ [47], while it shifts to higher wavelengths if NPs are embedded in a solid-state matrix $[84,88]$, the shift being higher the larger the matrix refractive index. Following the Maxwell Garnett approach [89] (see Supplementary Materials for further details), we have computed the imaginary part of the Ag NP in-plane polarizability for different values of the NP AR [90] and of the matrix dielectric function. Indeed, as occurs in the case of other metal oxide materials, the $\mathrm{MgO} \mathrm{UV}-\mathrm{Vis}$ dielectric function is known to vary with the film thickness $t$, becoming smaller than in the bulk for films thinner than $t \sim 250 \mathrm{~nm}[91,92]$. In Figure $6 \mathrm{c}$, the imaginary part of the NP polarizability is calculated for different values of $\mathrm{AR}$ ranging between 1.5 and 2.5, using the dielectric constants of bulk $\mathrm{Ag}$ and $\mathrm{MgO}$, taken from reference [93]. In this case, a red shift of the LSPR maximum from $\sim 500 \mathrm{~nm}$ to $\sim 570 \mathrm{~nm}$ is observed upon AR increasing. Figure $6 \mathrm{~d}$ shows, instead, the imaginary part of the NP polarizability calculated using the smaller dielectric constant of a thin $\mathrm{MgO}$ layer, as taken from the literature [94]. In this case, all the spectra are blue shifted, the AR $=2$ moving from 520 to $460 \mathrm{~nm}$, in fair agreement with the maximum position measured for the $1.5 \%$ coverage. As previously discussed, the distribution of NP AR values is expected to broaden with increasing NP film coverages-with larger NPs having higher AR - thus explaining the observed broadening of the LSPR peak. On the other hand, particle interconnections can also influence the values of plasmonic resonance mode at high coverages, contributing to the overall broadening $[95,96]$.

Eventually, the functionalized substrates were used to fabricate and test the overall electric performance of $\mathrm{Ag} / \mathrm{MgO}$-engineered PSCs, for different $\mathrm{NP}$ coverages. As shown in Figure 1c (right), the $\mathrm{Ag} / \mathrm{MgO}$ NPs are localized at the interface between the ETL m- $\mathrm{TiO}_{2}$ layer and the mixed-cation perovskite photoactive layer.

The summary of the main performance parameters-i.e., short circuit current density $\left(\mathrm{J}_{\mathrm{sc}}\right)$, open circuit voltage $\left(\mathrm{V}_{\mathrm{oc}}\right)$, fill factor $(\mathrm{FF})$ and power conversion efficiency (PCE) - is shown in Table 1 for different NP coverages; at least nine devices were tested for each coverage. The reference cell $(0.0 \%)$ presents an average PCE of $16.0 \% \pm 0.4 \%$. The best results are obtained for an NP surface coverage of about $1.5 \%$, which performs at an average 
efficiency of $16.5 \% \pm 0.8 \%$, corresponding to a relative improvement of $\sim 3 \%$ in PCE. For NP coverages above $3.5 \%$, the performance of the NP-engineered cells progressively deteriorates, possibly due to reduced transmissivity at the $\mathrm{TiO}_{2} / \mathrm{NP}$ interface, which reduces the fraction of light reaching the perovskite active layer [97]. For all measured devices, no perovskite degradation was visually observed, indicative of the active role played by $\mathrm{MgO}$ as an effective protective material of the $\mathrm{Ag}$ core from direct exposure to perovskite.

Table 1. Main parameters, with their standard deviations, for devices ranging between $0.0 \%$ and $10.0 \%$ of surface coverage in $\mathrm{Ag} / \mathrm{MgO} \mathrm{NPs}$ atop an $\mathrm{m}-\mathrm{TiO}_{2}$ layer.

\begin{tabular}{ccccc}
\hline $\begin{array}{c}\text { Ag/MgO } \\
\text { Coverage } \%\end{array}$ & $\mathbf{J}_{\mathbf{s c}}\left(\mathbf{m A} / \mathbf{c m}^{2}\right)$ & $\mathbf{V}_{\text {oc }}(\mathbf{V})$ & FF (\%) & PCE (\%) \\
\hline 0.0 & $21.6 \pm 0.3$ & $1.04 \pm 0.03$ & $71.1 \pm 1.0$ & $16.0 \pm 0.4$ \\
\hline 1.5 & $22.1 \pm 0.4$ & $1.07 \pm 0.03$ & $71.5 \pm 2.4$ & $16.5 \pm 0.8$ \\
\hline 3.2 & $21.6 \pm 0.7$ & $1.06 \pm 0.02$ & $69.7 \pm 2.8$ & $15.0 \pm 1.2$ \\
\hline 8.7 & $12.0 \pm 1.4$ & $1.00 \pm 0.03$ & $60.2 \pm 2.2$ & $8.4 \pm 1.0$ \\
\hline 10.0 & $7.3 \pm 0.7$ & $0.98 \pm 0.01$ & $50.9 \pm 3.3$ & $5.0 \pm 0.9$ \\
\hline
\end{tabular}

As shown in Table 1, the PCE enhancement observed for 1.5\% coverage is related to an increase in both $\mathrm{J}_{\mathrm{SC}}$ and $\mathrm{V}_{\mathrm{OC}}$. The best cell electrical parameters are reported in Table 2, showing a PCE value of $17.8 \%$, as compared to the $17.0 \%$ of the best-efficiency reference device, corresponding to an overall relative increment of about $5 \%$. Analogous relative increments in PCE enhancement have been reported in the literature for different types of core-shell NPs deposited or embedded in the ETL. For instance, in the cases of

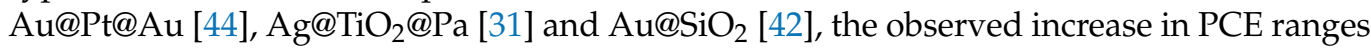
between 8 and $17 \%$.

Table 2. Main performance parameters for the best reference cell and the best optimized device with $\mathrm{Ag} / \mathrm{MgO} \mathrm{NPs}$.

\begin{tabular}{ccccc}
\hline & $\mathbf{J}_{\mathbf{s c}}\left(\mathbf{m A} / \mathbf{c m}^{\mathbf{2}}\right)$ & $\mathbf{V}_{\mathbf{o c}}(\mathbf{V})$ & FF (\%) & PCE (\%) \\
\hline Reference & 22.0 & 1.05 & 72.2 & 17.0 \\
\hline $\mathrm{Ag} / \mathrm{MgO} 1.5 \%$ & 22.6 & 1.08 & 71.9 & 17.8 \\
\hline
\end{tabular}

In Figure 7, the current density-voltage $(\mathrm{J}-\mathrm{V})$ curve for the best optimized device at about $1.5 \%$ coverage of $\mathrm{Ag} / \mathrm{MgO} \mathrm{NPs}$ is compared to the corresponding (best-performing) reference cell, at stabilized conditions for both devices.

As shown in Figure 7 and Table 2, embedding the $\mathrm{Ag} / \mathrm{MgO}$ NPs atop an $\mathrm{m}-\mathrm{TiO}_{2}$ layer reflected a significant enhancement of $\mathrm{V}_{\mathrm{OC}}$. By following the study of Yuan et al. [34], we suggest that the improvement of $\mathrm{V}_{\mathrm{OC}}$ may be due to a reduction in $\mathrm{TiO}_{2} / \mathrm{Ag} / \mathrm{MgO} \mathrm{NP}$ work function with respect to $\mathrm{TiO}_{2}$. In fact, under light illumination, due to the injection of carriers from $\mathrm{Ag} / \mathrm{MgO} \mathrm{NPs}$ to $\mathrm{TiO}_{2}$, the Fermi level is expected to increase, leading to reduced $\mathrm{TiO}_{2}$ work function. Finally, this reduction may enhance the built-in potential and increase the $\mathrm{V}_{\mathrm{OC}}[98]$.

Moreover, in Figure 8, the IPCE spectra of the best-performing cell and of the $(0 \%)$ reference cell are compared, along with the corresponding integrated current density $\left(\mathrm{J}_{\text {integrated }}\right)$. The observed enhancement in IPCE takes place in the whole (340-760) nm optical window, in agreement with previous results reported in the literature [99-101]. This broadband effect has been attributed to different NP-related effects, suggesting that, besides near-field LSPR-enhanced absorption, other mechanisms such as increased far-field scattering, facilitated charge-transfer and separation $[37,102]$ and reduction in the exciton binding energy $[42,48]$ may play a relevant role. 


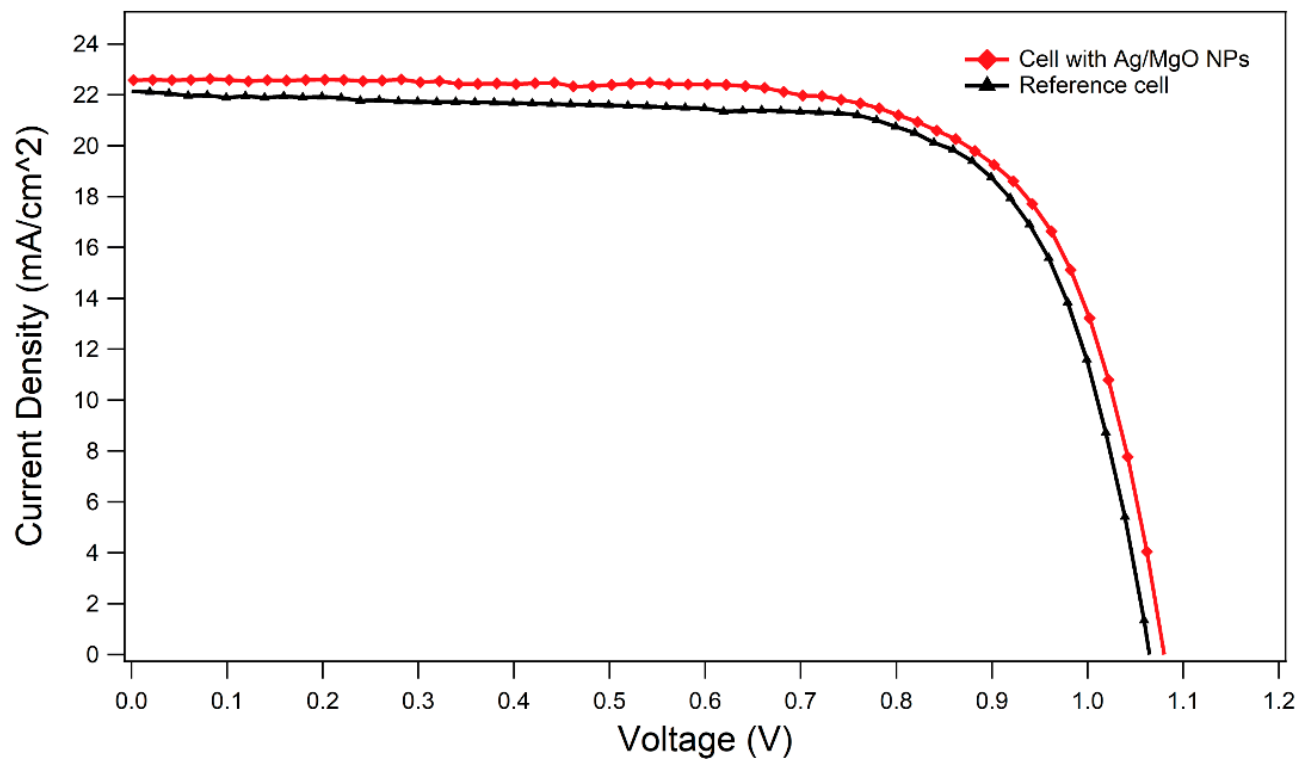

Figure 7. J-V curves for both the best reference cell without $\mathrm{Ag} / \mathrm{MgO}$ NPs (black curve) and the best optimized device with NPs (red curve).

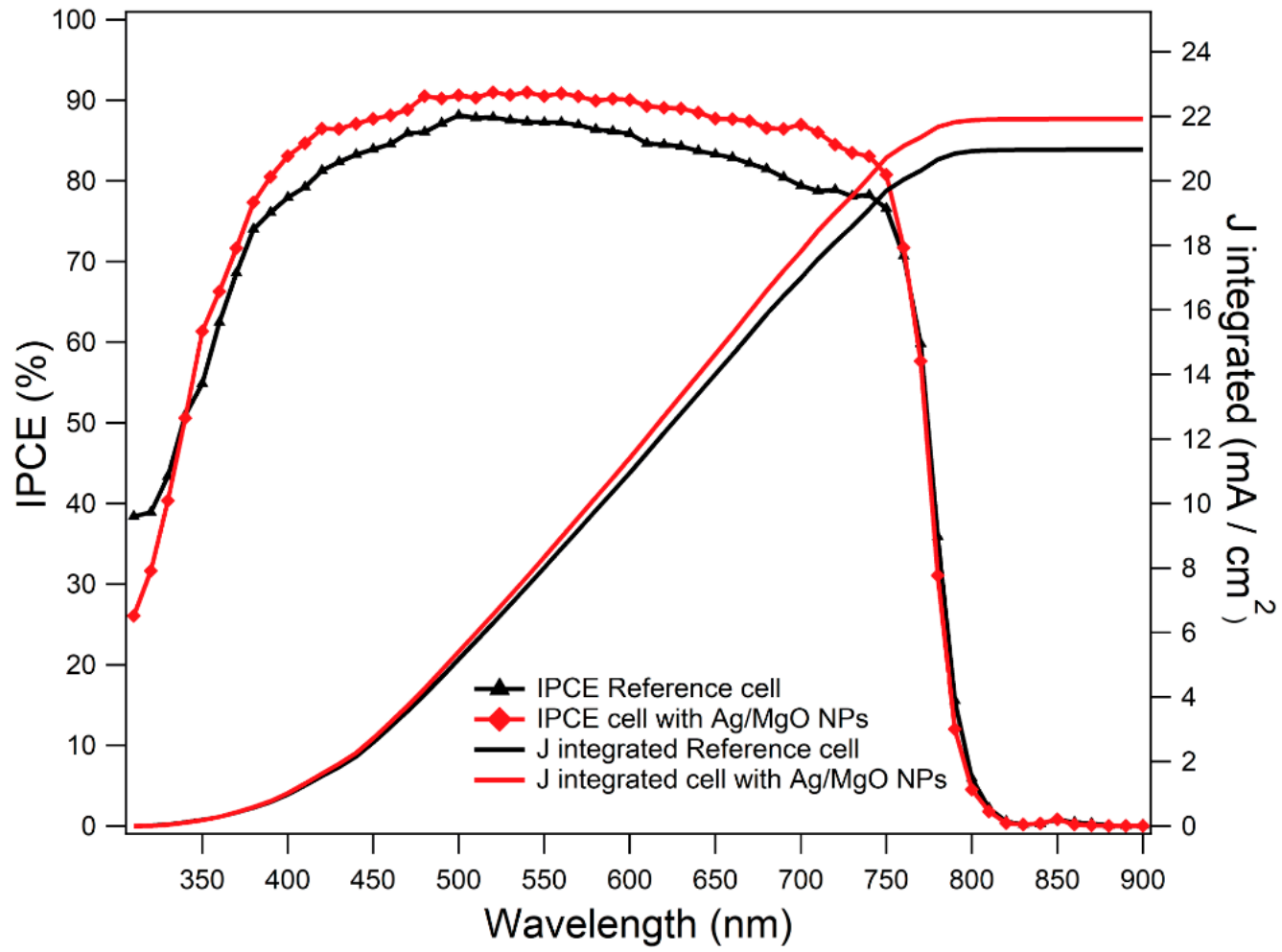

Figure 8. IPCE spectra for both the best-performing device with $\mathrm{Ag} / \mathrm{MgO} \mathrm{NPs}$ (red) and the best reference device (black) and their integrated current density; the J values registered are coherent with those shown in Table 2 under a solar simulator, with a percentage difference of $3 \%$ and $4.7 \%$ for the devices with and without NPs, respectively.

\section{Conclusions}

In this work, the magnetron-based physical deposition method was applied to incorporate novel NPs in thin-film perovskite solar devices, thus probing their properties and their effect on device performance enhancement. In particular, the structural properties of $\mathrm{Ag} / \mathrm{MgO} \mathrm{NPs}$ - deposited on a suitable mesh by a co-deposition method-are investigated 
by HR-TEM, showing the multi-twinning icosahedral structure of the Ag core, and providing evidence (through EDXS mapping) of the actual formation of the $\mathrm{MgO}$ overlayer. The morphological properties of $\mathrm{Ag} / \mathrm{MgO}$ NPs deposited on top of the $\mathrm{m}-\mathrm{TiO}_{2} \mathrm{ETL}$ layer by means of sequential-layer deposition were investigated through XPS, SEM and AFM, providing information on their lateral dimension and height distributions. For an NP coverage of $1.5 \%$, the mean value of the NP lateral dimension is $\mathrm{d}=8.0 \mathrm{~nm}$ while the mean height is $h=4 \mathrm{~nm}$, showing that NPs are characterized by a flattened spheroidal shape, with $\mathrm{AR} 2$. Furthermore, XPS measurements show the NPs' stability against thermal treatment up to $150{ }^{\circ} \mathrm{C}$, an important aspect to be considered for their actual use in real PSC devices. Optical loss data, taken with s-polarized UV-visible light in the $300-800 \mathrm{~nm}$, are dominated by the Ag LSPR absorption band, peaking at $\lambda \sim 420 \mathrm{~nm}$, together with a long-wavelength tail mainly attributed to diffuse scattering. Upon an NP coverage increase, the optical loss intensity increases and the LSPR peak broadens and red shifts; these changes are attributed to a change in the NP size and AR distributions and suggest the possibility of tuning the system optical response, as well as extending the plasmonic response to a broader spectral range, by changing the deposited NP amount and morphology. By embedding silver magnesia NPs at the interface between the photoactive layer (i.e., a triple-cation perovskite layer) and the $\mathrm{m}-\mathrm{TiO}_{2}$ electron transport layer in thin films of PSC devices, average efficiency increases of $\sim 3 \%$ were obtained, from $16.0 \%$ in the pristine device to $16.5 \%$ in the engineered $\mathrm{Ag} / \mathrm{MgO} \mathrm{NP}$ device at an optimized coverage value around $1.5 \%$. It is noted that the moderate increase in device performances-as compared with other NP-engineered cells reported in the literature-becomes quite remarkable if we consider that in the tested devices, NPs were mainly localized at the surface of the mesoporous substrate. This increase is mainly related to an enhancement in the device short circuit current and open circuit voltage, while the IPCE spectrum shows that this increase is distributed on all wavelengths. This suggests, in agreement with the literature, that Ag LSPR may not be the main source of the observed efficiency enhancement, while other mechanisms such as diffuse light scattering, enhanced charge separation and reduction in exciton binding energy also have to be considered. In parallel, the improved $\mathrm{V}_{\mathrm{OC}}$ suggests an upward shift of $\mathrm{m}-\mathrm{TiO}_{2}$ work function due to an efficient charge transfer from $\mathrm{Ag} / \mathrm{MgO}$ $\mathrm{NPs}$ and $\mathrm{m}-\mathrm{TiO}_{2}$. This work presents our physical deposition method, based on a gas aggregation nanocluster source, as an innovative, versatile, and solvent-free strategy for plasmonic NP engineering, which will allow the exploration of different combinations of metal cores and shell/protective layer materials, aiming at the fabrication of solar devices with increased current density and efficiency.

Supplementary Materials: The following are available online at https:/ /www.mdpi.com/article/10

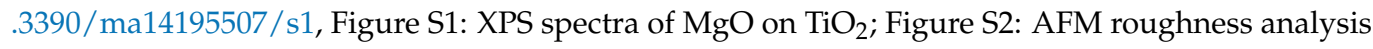
of the flat $\mathrm{TiO}_{2}$; polarizability calculation within the Maxwell Garnett model (Equation).

Author Contributions: Conceptualization, M.C., V.D.R., A.A., S.P., P.M., S.D. and A.D.C.; Data curation, M.C.; Formal analysis, M.C.; Funding acquisition, V.D.R., S.D. and A.D.C.; Investigation, M.C. and P.M.; Resources, A.A., S.P., G.P., L.P. and G.B.; Supervision, P.M., A.D.C., V.D.R. and S.D.; Writing-original draft, M.C.; Writing—review and editing, M.C., P.M., G.B., G.P., L.P., A.A., S.P., A.D.C., V.D.R. and S.D. All authors have read and agreed to the published version of the manuscript.

Funding: This research received no external funding.

Informed Consent Statement: Not applicable.

Data Availability Statement: Data is contained within the article and Supplementary Materials.

Acknowledgments: The authors would like to thank Centro Interdipartimentale Grandi Strumenti (CIGS) for the usage of SEM and TEM facilities and for their professionalism and caring.

Conflicts of Interest: The authors declare no competing financial interest. 


\section{References}

1. Jeong, J.; Kim, M.; Seo, J.; Lu, H.; Ahlawat, P.; Mishra, A.; Yang, Y.; Hope, M.A.; Eickemeyer, F.T.; Kim, M.; et al. Pseudo-halide anion engineering for $\alpha$-FAPbI3 perovskite solar cells. Nature 2021, 592, 381-385. [CrossRef]

2. Best Research-Cell Efficiency Chart I Photovoltaic Research I NREL. Available online: https:/ / www.nrel.gov/pv/cell-efficiency. html (accessed on 26 March 2021).

3. Webb, T.; Sweeney, S.J.; Zhang, W. Device Architecture Engineering: Progress toward Next Generation Perovskite Solar Cells. Adv. Funct. Mater. 2021, 2103121. [CrossRef]

4. Chen, J.; Park, N. Materials and Methods for Interface Engineering toward Stable and Efficient Perovskite Solar Cells. ACS Energy Lett. 2020, 5, 2742-2786. [CrossRef]

5. Roose, B.; Wang, Q.; Abate, A. The Role of Charge Selective Contacts in Perovskite Solar Cell Stability. Adv. Energy Mater. 2019, 9, 1803140. [CrossRef]

6. Liu, C.; Cheng, Y.; Ge, Z. Chem Soc Rev Understanding of perovskite crystal growth and film formation in scalable deposition processes. Chem. Soc. Rev 2020, 49, 1653-1687. [CrossRef] [PubMed]

7. Thrithamarassery Gangadharan, D.; Ma, D. Searching for stability at lower dimensions: Current trends and future prospects of layered perovskite solar cells. Energy Environ. Sci. 2019, 12, 2860-2889. [CrossRef]

8. Fakharuddin, A.; Schmidt-Mende, L.; Garcia-Belmonte, G.; Jose, R.; Mora-Sero, I. Interfaces in perovskite solar cells. Adv. Electron. Mater. 2017, 7, 1-44. [CrossRef]

9. Giordano, F.; Abate, A.; Pablo, J.; Baena, C.; Saliba, M.; Matsui, T.; Im, S.H.; Zakeeruddin, S.M.; Nazeeruddin, M.K.; Hagfeldt, A.; et al. Enhanced electronic properties in mesoporous $\mathrm{TiO}_{2}$ via lithium doping for high-efficiency perovskite solar cells. Nat. Commun. 2016, 7, 1-6. [CrossRef]

10. Amalathas, A.P.; Landov, L.; Huminiuc, T. Elucidating the role of $\mathrm{TiCl}_{4}$ post-treatment on percolation of $\mathrm{TiO}_{2}$ electron transport layer in perovskite solar cells. J. Phys. D Appl. Phys. 2020, 53, 385501. [CrossRef]

11. Zhen, C.; Wu, T.; Chen, R.; Wang, L.; Liu, G.; Cheng, H. Strategies for Modifying $\mathrm{TiO}_{2}$ Based Electron Transport Layers to Boost Perovskite Solar Cells. ACS Sustain. Chem. Eng. 2019, 7, 4586-4618. [CrossRef]

12. Di Carlo, A.; Agresti, A.; Brunetti, F.; Pescetelli, S. Two-dimensional materials in perovskite solar cells. J. Phys. Energy 2020, 2, 031003. [CrossRef]

13. Taheri, B.; Nia, N.Y.; Agresti, A.; Pescetelli, S.; Ciceroni, C.; Del Rio Castillo, A.E.; Cinà, L.; Bellani, S.; Bonaccorso, F.; Di Carlo, A. Graphene-engineered automated sprayed mesoscopic structure for perovskite device scaling-up. 2D Mater. 2018, 5, 045034 . [CrossRef]

14. Agresti, A.; Pescetelli, S.; Taheri, B.; Del Rio Castillo, A.E.; Cinà, L.; Bonaccorso, F.; Di Carlo, A. Graphene-Perovkite solar cells exceed 18\% efficiency: A stability study. ChemSusChem 2016, 9, 2609-2619. [CrossRef] [PubMed]

15. Agresti, A.; Pescetelli, S.; Palma, A.L.; Martin-Garcia, B.; Najafi, L.; Bellani, S.; Moreels, I.; Prato, M.; Bonaccorso, F.; Di Carlo, A. Two-dimensional (2D) Material Interface Engineering for Efficient Perovskite Large-area Modules. ACS Energy Lett. 2019, 4, 1862-1871. [CrossRef]

16. Biccari, F.; Gabelloni, F.; Burzi, E.; Gurioli, M.; Pescetelli, S.; Agresti, A.; Del Rio Castillo, A.E.; Ansaldo, A.; Kymakis, E.; Bonaccorso, F.; et al. Graphene-Based Electron Transport Layers in Perovskite Solar Cells: A Step-Up for an Efficient Carrier Collection. Adv. Energy Mater. 2017, 7, 1701349. [CrossRef]

17. Agresti, A.; Pescetelli, S.; Cinà, L.; Konios, D.; Kakavelakis, G.; Kymakis, E.; Carlo, A. Di Efficiency and Stability Enhancement in Perovskite Solar Cells by Inserting Lithium-Neutralized Graphene Oxide as Electron Transporting Layer. Adv. Funct. Mater. 2016, 26, 2686-2694. [CrossRef]

18. Agresti, A.; Pescetelli, S.; Najafi, L.; Castillo, A.E.D.R.; Busby, Y.; Carlo, A. Di Graphene and related 2D materials for high efficient and stable perovskite solar cells. In Proceedings of the 17th IEEE International Conference on Nanotechnology Pittsburgh, Pittsburgh, PA, USA, 25-28 July 2017; pp. 145-150.

19. Agresti, A.; Pazniak, A.; Pescetelli, S.; Di Vito, A.; Rossi, D.; Pecchia, A.; Auf der Maur, M.; Liedl, A.; Larciprete, R.; Kuznetsov, D.V.; et al. Titanium-carbide MXenes for work function and interface engineering in perovskite solar cells. Nat. Mater. 2019, 18, 1228-1234. [CrossRef]

20. Saranin, D.; Pescetelli, S.; Pazniak, A.; Rossi, D.; Liedl, A.; Yakusheva, A.; Luchnikov, L.; Podgorny, D.; Gostischev, P.; Didenko, S.; et al. Transition metal carbides (MXenes) for efficient NiO-based inverted perovskite solar cells. Nano Energy 2021, 82, 105771. [CrossRef]

21. Xu, Y.; Cao, H.; Xue, Y.; Li, B.; Cai, W. Liquid-Phase Exfoliation of Graphene: An Overview on Exfoliation Media, Techniques, and Challenges. Nanomaterials 2018, 8, 942. [CrossRef]

22. Del Rio Castillo, A.E.; Pellegrini, V.; Ansaldo, A.; Ricciardella, F.; Sun, H.; Marasco, L.; Buha, J.; Dang, Z.; Gagliani, L.; Lago, E.; et al. High-yield production of 2D crystals by wet-jet milling. Mater. Horizons 2018, 5, 890-904. [CrossRef]

23. Li, Y.; Kou, Z.; Feng, J.; Sun, H. Plasmon-enhanced organic and perovskite solar cells with metal nanoparticles. Nanophotonics 2020, 9, 3111-3133. [CrossRef]

24. Astruc, D. Nanoparticles and Catalysis; Wiley-VCH: Weinheim, Germany, 2008; ISBN 9783527315727.

25. Westphalen, M.; Kreibig, U.; Rostalski, J.; Lüth, H.; Meissner, D. Metal cluster enhanced organic solar cells. Sol. Energy Mater. Sol. Cells 2000, 61, 97-105. [CrossRef] 
26. Derkacs, D.; Lim, S.H.; Matheu, P.; Mar, W.; Yu, E.T. Improved performance of amorphous silicon solar cells via scattering from surface plasmon polaritons in nearby metallic nanoparticles. Appl. Phys. Lett. 2006, 89, 093103. [CrossRef]

27. Pillai, S.; Catchpole, K.R.; Trupke, T.; Green, M.A. Surface plasmon enhanced silicon solar cells. J. Appl. Phys. 2007, 101, 093105. [CrossRef]

28. Catchpole, K.R.; Polman, A. Design principles for particle plasmon enhanced solar cells. Appl. Phys. Lett. 2008, 93, 191113. [CrossRef]

29. Kim, S.S.; Na, S.I.; Jo, J.; Kim, D.Y.; Nah, Y.C. Plasmon enhanced performance of organic solar cells using electrodeposited Ag nanoparticles. Appl. Phys. Lett. 2008, 93, 073307. [CrossRef]

30. Park, J.; Park, N.; Varlamov, S. Optimum surface condition for plasmonic Ag nanoparticles in polycrystalline silicon thin film solar cells. Appl. Phys. Lett. 2014, 104, 033903. [CrossRef]

31. Yao, K.; Zhong, H.; Liu, Z.; Xiong, M.; Leng, S.; Zhang, J.; Xu, Y.X.; Wang, W.; Zhou, L.; Huang, H.; et al. Plasmonic Metal Nanoparticles with Core-Bishell Structure for High-Performance Organic and Perovskite Solar Cells. ACS Nano 2019, 13, 5397-5409. [CrossRef] [PubMed]

32. Hao, J.; Hao, H.; Li, J.; Shi, L.; Zhong, T.; Zhang, C.; Dong, J.; Xing, J.; Liu, H.; Zhang, Z. Light trapping effect in perovskite solar cells by the addition of ag nanoparticles, using textured substrates. Nanomaterials 2018, 8, 815. [CrossRef] [PubMed]

33. Li, R.; Li, B.Q.; Wang, W. Forward scattering nanoparticles based nanostructure for light trapping over solar spectrum. AIP Adv. 2019, 9, 085119. [CrossRef]

34. Yuan, Z.; Wu, Z.; Bai, S.; Xia, Z.; Xu, W.; Song, T.; Wu, H.; Xu, L.; Si, J.; Jin, Y.; et al. Hot-Electron Injection in a Sandwiched $\mathrm{TiO}_{x}-\mathrm{Au}-\mathrm{TiO}_{x}$ Structure for High-Performance Planar Perovskite Solar Cells. Adv. Energy Mater. 2015, 5, 1500038. [CrossRef]

35. Furube, A.; Du, L.; Hara, K.; Katoh, R.; Tachiya, M. Ultrafast plasmon-induced electron transfer from gold nanodots into TiO2 nanoparticles. J. Am. Chem. Soc. 2007, 129, 14852-14853. [CrossRef] [PubMed]

36. Giugni, A.; Torre, B.; Toma, A.; Francardi, M.; Malerba, M.; Alabastri, A.; Proietti Zaccaria, R.; Stockman, M.I.; Di Fabrizio, E. Hot-electron nanoscopy using adiabatic compression of surface plasmons. Nat. Nanotechnol. 2013, 8, 845-852. [CrossRef]

37. Dong, H.; Lei, T.; Yuan, F.; Xu, J.; Niu, Y.; Jiao, B.; Zhang, Z.; Ding, D.; Hou, X.; Wu, Z. Plasmonic enhancement for high efficient and stable perovskite solar cells by employing "hot spots" Au nanobipyramids. Org. Electron. 2018, 60, 1-8. [CrossRef]

38. Solzi, M.; Pernechele, C.; Calestani, G.; Villani, M.; Gaboardi, M.; Migliori, A. Non-interacting hard ferromagnetic L10 FePt nanoparticles embedded in a carbon matrix. J. Mater. Chem. 2011, 21, 18331-18338. [CrossRef]

39. Svanström, S.; Jacobsson, T.J.; Boschloo, G.; Johansson, E.M.J.; Rensmo, H.; Cappel, U.B. Degradation Mechanism of Silver Metal Deposited on Lead Halide Perovskites. ACS Appl. Mater. Interfaces 2020, 12, 7212-7221. [CrossRef]

40. Luo, Q.; Zhang, C.; Deng, X.; Zhu, H.; Li, Z.; Wang, Z.; Chen, X.; Huang, S. Plasmonic Effects of Metallic Nanoparticles on Enhancing Performance of Perovskite Solar Cells. ACS Appl. Mater. Interfaces 2017, 9, 34821-34832. [CrossRef]

41. Kluczyk-Korch, K.; David, C.; Jacak, W.; Jacak, J. Application of core-shell metallic nanoparticles in hybridized perovskite solar cell-various channels of plasmon photovoltaic effect. Materials 2019, 12, 3192. [CrossRef]

42. Zhang, W.; Saliba, M.; Stranks, S.D.; Sun, Y.; Shi, X.; Wiesner, U.; Snaith, H.J. Enhancement of perovskite-based solar cells employing core-shell metal nanoparticles. Nano Lett. 2013, 13, 4505-4510. [CrossRef]

43. Li, Z.; Wang, R.; Xue, J.; Xing, X.; Yu, C.; Huang, T.; Chu, J.; Wang, K.L.; Dong, C.; Wei, Z.; et al. Core-Shell ZnO@SnO2 Nanoparticles for Efficient Inorganic Perovskite Solar Cells. J. Am. Chem. Soc. 2019, 141, 17610-17616. [CrossRef]

44. Wang, B.; Zhu, X.; Li, S.; Chen, M.; Liu, N.; Yang, H.; Ran, M.; Lu, H.; Yang, Y. Enhancing the Photovoltaic Performance of Perovskite Solar Cells Using Plasmonic Au@Pt@Au Core-Shell Nanoparticles. Nanomaterials 2019, 9, 1263. [CrossRef] [PubMed]

45. Lu, Z.; Pan, X.; Ma, Y.; Li, Y.; Zheng, L.; Zhang, D.; Xu, Q.; Chen, Z.; Wang, S.; Qu, B.; et al. Plasmonic-enhanced perovskite solar cells using alloy popcorn nanoparticles. RSC Adv. 2015, 5, 11175-11179. [CrossRef]

46. Ginting, R.T.; Kaur, S.; Lim, D.K.; Kim, J.M.; Lee, J.H.; Lee, S.H.; Kang, J.W. Plasmonic Effect of Gold Nanostars in Highly Efficient Organic and Perovskite Solar Cells. ACS Appl. Mater. Interfaces 2017, 9, 36111-36118. [CrossRef]

47. Kreibig, U.; Vollmer, M. Optical Properties of Metal Clusters; Springer Series in Materials Science; Springer: Berlin/Heidelberg, Germany, 1995; Volume 25, ISBN 978-3-642-08191-0.

48. Saliba, M.; Zhang, W.; Burlakov, V.M.; Stranks, S.D.; Sun, Y.; Ball, J.M.; Johnston, M.B.; Goriely, A.; Wiesner, U.; Snaith, H.J. Plasmonic-Induced Photon Recycling in Metal Halide Perovskite Solar Cells. Adv. Funct. Mater. 2015, 25, 5038-5046. [CrossRef]

49. Kumar, V.S.S.; Rao, K.V. Synthesis and study of ultrasonic parameters of MgO-ethylene glycol nanofluids. J. Nanofluids 2018, 7, 269-274. [CrossRef]

50. D'Addato, S.; Pinotti, D.; Spadaro, M.C.; Paolicelli, G.; Grillo, V.; Valeri, S.; Pasquali, L.; Bergamini, L.; Corni, S. Influence of size, shape and core-shell interface on surface plasmon resonance in Ag and Ag@MgO nanoparticle films deposited on Si/SiOx. Beilstein J. Nanotechnol. 2015, 6, 404-413. [CrossRef]

51. Zhang, C.; Luo, Q.; Shi, J.; Yue, L.; Wang, Z.; Chen, X.; Huang, S. Efficient perovskite solar cells by combination use of Au nanoparticles and insulating metal oxide. Nanoscale 2017, 9, 2852-2864. [CrossRef]

52. Wang, J.; Qin, M.; Tao, H.; Ke, W.; Chen, Z.; Wan, J.; Qin, P.; Xiong, L.; Lei, H.; Yu, H.; et al. Performance enhancement of perovskite solar cells with Mg-doped TiO2 compact film as the hole-blocking layer. Appl. Phys. Lett. 2015, 106, 121104. [CrossRef]

53. Spadaro, M.C.; D’Addato, S.; Luches, P.; Valeri, S.; Grillo, V.; Rotunno, E.; Roldan, M.A.; Pennycook, S.J.; Ferretti, A.M.; Capetti, E.; et al. Tunability of exchange bias in $\mathrm{Ni@NiO} \mathrm{core-shell} \mathrm{nanoparticles} \mathrm{obtained} \mathrm{by} \mathrm{sequential} \mathrm{layer} \mathrm{deposition.} \mathrm{Nanotechnology}$ 2015, 26, 405704. [CrossRef] [PubMed] 
54. D'Addato, S.; Gunnella, R.; Borgatti, F.; Felici, R.; Finetti, P. Atom geometry of nanostructured Fe films grown on c(2 $\times 2)-\mathrm{N} / \mathrm{Cu}(1$ 0 0) surface: An investigation by X-ray absorption spectroscopy with multishell analysis. Surf. Sci. 2007, 601, 329-340. [CrossRef]

55. Bansmann, J.; Baker, S.H.; Binns, C.; Blackman, J.A.; Bucher, J.P.; Dorantes-Dávila, J.; Dupuis, V.; Favre, L.; Kechrakos, D.; Kleibert, A.; et al. Magnetic and structural properties of isolated and assembled clusters. Surf. Sci. Rep. 2005, 56, 189-275. [CrossRef]

56. Llamosa, D.; Ruano, M.; Martínez, L.; Mayoral, A.; Roman, E.; García-Hernández, M.; Huttel, Y. The ultimate step towards a tailored engineering of core@shell and core@shell@shell nanoparticles. Nanoscale 2014, 6, 13483-13486. [CrossRef] [PubMed]

57. Razza, S.; Pescetelli, S.; Agresti, A.; Carlo, A. Di Laser Processing Optimization for Large-Area Perovskite Solar Modules. Energies 2021, 14, 1069. [CrossRef]

58. Larciprete, R.; Agresti, A.; Pescetelli, S.; Pazniak, H.; Liedl, A.; Lacovig, P.; Lizzit, D.; Tosi, E.; Lizzit, S.; Carlo, A. Di Physical Stress. Materials 2021, 14, 3954. [CrossRef]

59. Polyakov, A.Y.; Smirnov, N.B.; Shchemerov, I.V.; Saranin, D.S.; Le, T.S.; Didenko, S.I.; Kuznetsov, D.V.; Agresti, A.; Pescetelli, S.; Matteocci, F.; et al. Trap states in multication mesoscopic perovskite solar cells: A deep levels transient spectroscopy investigation. Appl. Phys. Lett. 2018, 113, 263501. [CrossRef]

60. D'Addato, S.; Grillo, V.; Altieri, S.; Tondi, R.; Valeri, S.; Frabboni, S. Structure and stability of nickel/nickel oxide core-shell nanoparticles. J. Phys. Condens. Matter 2011, 23, 175003. [CrossRef]

61. D’Addato, S.; Grillo, V.; Di Bona, A.; Luches, P.; Frabboni, S.; Valeri, S.; Lupo, P.; Casoli, F.; Albertini, F. Controlled co-deposition of FePt nanoparticles embedded in MgO: A detailed investigation of structure and electronic and magnetic properties. Nanotechnology 2013, 24, 495703. [CrossRef] [PubMed]

62. Lucas, G.; Burdet, P.; Cantoni, M.; Hébert, C. Multivariate statistical analysis as a tool for the segmentation of 3D spectral data. Micron 2013, 52, 49-56. [CrossRef]

63. Agresti, A.; Cinà, L.; Pescetelli, S.; Taheri, B.; Di Carlo, A. Stability of dye-sensitized solar cell under reverse bias condition: Resonance Raman spectroscopy combined with spectrally resolved analysis by transmittance and efficiency mapping. Vib. Spectrosc. 2016, 84, 106-117. [CrossRef]

64. Agresti, A.; Pescetelli, S.; Quatela, A.; Mastroianni, S.; Brown, T.M.; Reale, A.; Bignozzi, C.A.; Caramori, S.; Di Carlo, A. Micro-Raman analysis of reverse bias stressed dye-sensitized solar cells. RSC Adv. 2014, 4, 12366. [CrossRef]

65. Agresti, A.; Berionni Berna, B.; Pescetelli, S.; Catini, A.; Menchini, F.; Di Natale, C.; Paolesse, R.; Di Carlo, A. Copper-Based Corrole as Thermally Stable Hole Transporting Material for Perovskite Photovoltaics. Adv. Funct. Mater. 2020, 30, 1-11. [CrossRef]

66. Grätzel, M. Photoelectrochemical cells. Nature 2001, 414, 338-344. [CrossRef] [PubMed]

67. Chung, I.; Lee, B.; He, J.; Chang, R.P.H.; Kanatzidis, M.G. All-solid-state dye-sensitized solar cells with high efficiency. Nature 2012, 485, 486-489. [CrossRef] [PubMed]

68. Deepa, M.; Salado, M.; Calio, L.; Kazim, S.; Shivaprasad, S.M.; Ahmad, S. Cesium power: Low Cs+ levels impart stability to perovskite solar cells. Phys. Chem. Chem. Phys. 2017, 19, 4069-4077. [CrossRef] [PubMed]

69. Kar, A. Nanoelectronics and Materials Development. Nanoelectron. Mater. Dev. 2016. [CrossRef]

70. Higgins, M.; Ely, F.; Nome, R.C.; Nome, R.A.; dos Santos, D.P.; Choi, H.; Nam, S.; Quevedo-Lopez, M. Enhanced reproducibility of planar perovskite solar cells by fullerene doping with silver nanoparticles. J. Appl. Phys. 2018, 124, 065306. [CrossRef]

71. Ma, J.; Yang, G.; Qin, M.; Zheng, X.; Lei, H.; Chen, C.; Chen, Z.; Guo, Y.; Han, H.; Zhao, X.; et al. MgO Nanoparticle Modified Anode for Highly Efficient SnO2-Based Planar Perovskite Solar Cells. Adv. Sci. 2017, 4, 1700031. [CrossRef]

72. Marks, L.D. Experimental studies of small particle structures. Reports Prog. Phys. 1994, 57, 603-649. [CrossRef]

73. Mackay, A.L. A dense non-crystallographic packing of equal spheres. Acta Crystallogr. 1962, 15, 916-918. [CrossRef]

74. Ino, S. Stability of Multiply-Twinned Particles. J. Phys. Soc. Japan 1969, 27, 941-953. [CrossRef]

75. Barke, I.; Hartmann, H.; Rupp, D.; Flückiger, L.; Sauppe, M.; Adolph, M.; Schorb, S.; Bostedt, C.; Treusch, R.; Peltz, C.; et al. The 3D-architecture of individual free silver nanoparticles captured by X-ray scattering. Nat. Commun. 2015, 6, 1-7. [CrossRef]

76. Kleibert, A.; Bulut, F.; Gebhardt, R.K.; Rosellen, W.; Sudfeld, D.; Passig, J.; Bansmann, J.; Meiwes-Broer, K.H.; Getzlaff, M. Correlation of shape and magnetic anisotropy of supported mass-filtered Fe and FeCo alloy nanoparticles on W(110). J. Phys. Condens. Matter 2008, 20, 445005. [CrossRef]

77. Kleibert, A.; Rosellen, W.; Getzlaff, M.; Bansmann, J.; Wiedwald, U.; Ziemann, P. Structure, morphology, and magnetic properties of Fe nanoparticles deposited onto single-crystalline surfaces. Beilstein J. Nanotechnol. 2011, 2, 47-56. [CrossRef]

78. Ito, S.; Zakeeruddin, S.M.; Humphry-Baker, R.; Liska, P.; Charvet, R.; Comte, P.; Nazeeruddin, M.K.; Péchy, P.; Takata, M.; Miura,

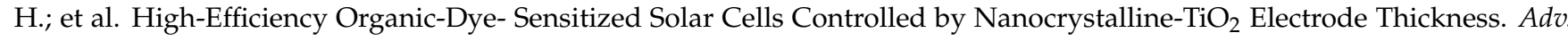
Mater. 2006, 18, 1202-1205. [CrossRef]

79. Collins, T.J. ImageJ for microscopy. Biotechniques 2007, 43, S25-S30. [CrossRef]

80. O'Grady, K.; Bradbury, A. Particle size analysis in ferrofluids. J. Magn. Magn. Mater. 1983, 39, 91-94. [CrossRef]

81. D'Addato, S.; Gragnaniello, L.; Valeri, S.; Rota, A.; Di Bona, A.; Spizzo, F.; Panozaqi, T.; Schifano, S.F. Morphology and magnetic properties of size-selected Ni nanoparticle films. J. Appl. Phys. 2010, 107, 104318. [CrossRef]

82. Getzlaff, M.; Bansmann, J.; Bulut, F.; Gebhardt, R.K.; Kleibert, A.; Meiwes-Broer, K.H. Structure, composition and magnetic properties of size-selected FeCo alloy clusters on surfaces. Appl. Phys. A Mater. Sci. Process. 2006, 82, 95-101. [CrossRef]

83. Mesquita, I.; Andrade, L.; Mendes, A. Temperature Impact on Perovskite Solar Cells Under Operation. ChemSusChem 2019, 12, 2186-2194. [CrossRef] 
84. Pelli Cresi, J.S.; Silvagni, E.; Bertoni, G.; Spadaro, M.C.; Benedetti, S.; Valeri, S.; D'Addato, S.; Luches, P. Optical and electronic properties of silver nanoparticles embedded in cerium oxide. J. Chem. Phys. 2020, 152, 114704. [CrossRef]

85. Stenzel, O. The Physics of Thin Film Optical Spectra-An Introduction I Olaf Stenzel; Springer: Berlin/Heidelberg, Germany, 2005.

86. Gibaud, A.; Vignaud, G. Specular reflectivity from smooth and rough surfaces. Lect. Notes Phys. 2009, 770, 85-131. [CrossRef]

87. Simonsen, I.; Lazzari, R.; Jupille, J.; Roux, S. Numerical modeling of the optical response of supported metallic particles. Phys. Rev. B Condens. Matter Mater. Phys. 2000, 61, 7722-7733. [CrossRef]

88. Noguez, C. Optical properties of isolated and supported metal nanoparticles. Opt. Mater. 2005, 27, 1204-1211. [CrossRef]

89. Granqvist, C.G.; Hunderi, O. Optical properties of ultrafine gold particles. Phys. Rev. B 1977, 16, 3513-3534. [CrossRef]

90. Pascua, L.; Stavale, F.; Nilius, N.; Freund, H.J. Ag/ZnO hybrid systems studied with scanning tunnelling microscopy-based luminescence spectroscopy. J. Appl. Phys. 2016, 119, 095310. [CrossRef]

91. Güney, H.; İskenderoğlu, D. Synthesis of MgO thin films grown by SILAR technique. Ceram. Int. 2018, 44, 7788-7793. [CrossRef]

92. Shin, D.Y.; Kim, K.N. Synthesis of MgO Thin Film Deposited on Soda Lime Glass by Sol-Gel Process. Mater. Sci. Forum 2008, 569, 61-64. [CrossRef]

93. Edward, P. Handbook of Optical Constants of Solids. Available online: http:/ / store.elsevier.com/product.jsp?isbn=9780125444231 (accessed on 26 March 2021).

94. Aadim, K.A. Preparation single layer of (MgO) as antireflection coating using PLD technique. Iraqi J. Phys. 2018, 16, 39-46. [CrossRef]

95. Noguez, C. Surface plasmons on metal nanoparticles: The influence of shape and physical environment. J. Phys. Chem. C 2007, 111, 3606-3619. [CrossRef]

96. Cha, H.; Lee, D.; Yoon, J.H.; Yoon, S. Plasmon coupling between silver nanoparticles: Transition from the classical to the quantum regime. J. Colloid Interface Sci. 2016, 464, 18-24. [CrossRef] [PubMed]

97. Li, S.; Zhu, X.; Wang, B.; Qiao, Y.; Liu, W.; Yang, H.; Liu, N.; Chen, M.; Lu, H.; Yang, Y. Influence of Ag Nanoparticles with Different Sizes and Concentrations Embedded in a TiO2 Compact Layer on the Conversion Efficiency of Perovskite Solar Cells. Nanoscale Res. Lett. 2018, 13, 210. [CrossRef]

98. Moakhar, R.S.; Gholipour, S.; Masudy-Panah, S.; Seza, A.; Mehdikhani, A.; Riahi-Noori, N.; Tafazoli, S.; Timasi, N.; Lim, Y.-F.; Saliba, M. Recent Advances in Plasmonic Perovskite Solar Cells. Adv. Sci. 2020, 7, 1902448. [CrossRef]

99. Ma, X.; Ma, B.; Yu, T.; Xu, X.; Zhang, L.; Wang, W.; Cao, K.; Deng, L.; Chen, S.; Huang, W. Indepth Studies on Working Mechanism of Plasmon-Enhanced Inverted Perovskite Solar Cells Incorporated with Ag@SiO2 Core-Shell Nanocubes. ACS Appl. Energy Mater. 2019, 2, 3605-3613. [CrossRef]

100. Bao, Z.; Fu, N.; Qin, Y.; Lv, J.; Wang, Y.; He, J.; Hou, Y.; Jiao, C.; Chen, D.; Wu, Y.; et al. Broadband Plasmonic Enhancement of High-Efficiency Dye-Sensitized Solar Cells by Incorporating Au@Ag@SiO2 Core-Shell Nanocuboids. ACS Appl. Mater. Interfaces 2020, 12, 538-545. [CrossRef] [PubMed]

101. Juan, F.; Wu, Y.; Shi, B.; Wang, M.; Wang, M.; Xu, F.; Jia, J.; Wei, H.; Yang, T.; Cao, B. Plasmonic Au Nanooctahedrons Enhance Light Harvesting and Photocarrier Extraction in Perovskite Solar Cell. ACS Appl. Energy Mater. 2021, 4, 3201-3209. [CrossRef]

102. Fan, R.; Wang, L.; Chen, Y.; Zheng, G.; Li, L.; Li, Z.; Zhou, H. Tailored Au@TiO 2 nanostructures for the plasmonic effect in planar perovskite solar cells. J. Mater. Chem. A 2017, 5, 12034-12042. [CrossRef] 